\title{
Inclusion Complexes of Non-Steroidal Anti-Inflammatory Drugs with Cyclodextrins: A Systematic Review
}

\author{
Gustavo Marinho Miranda ${ }^{1}{ }^{(}$, Vitória Ohana Ramos e Santos ${ }^{1}$, Jonatas Reis Bessa ${ }^{2}{ }^{\circledR}$, Yanna C. F. Teles ${ }^{3}{ }^{1}$, \\ Setondji Cocou Modeste Alexandre Yahouédéhou ${ }^{1}$, Marilda Souza Goncalves ${ }^{1}$ and Jaime Ribeiro-Filho ${ }^{1, *(1)}$ \\ 1 Laboratory of Investigation in Genetics and Translational Hematology, Gonçalo Moniz Institute (IGM), \\ Oswaldo Cruz Foundation (FIOCRUZ), Salvador, BA 40296-710, Brazil; \\ gustavobiomed116@gmail.com (G.M.M.); vitoria.ohana@outlook.com (V.O.R.eS.); \\ modya006@yahoo.fr (S.C.M.A.Y.); marilda.goncalves@fiocruz.br (M.S.G.) \\ 2 Institute of Psychology (IPS), Federal University of Bahia (UFBA), Salvador, BA 40170-055, Brazil; \\ jonatas.reisbessa@gmail.com \\ 3 Agrarian Sciences Center (CCA), Department of Chemistry and Physics (DQF), Federal University of \\ Paraiba (UFPB), Areia, PB 58397-000, Brazil; yanna@cca.ufpb.br \\ * Correspondence: jaime.ribeiro@fiocruz.br; Tel.: +55-71-3126-2226
}

Citation: Miranda, G.M.; Santos, V.O.R.e; Bessa, J.R.; Teles, Y.C.F.; Yahouédéhou, S.C.M.A.; Goncalves, M.S.; Ribeiro-Filho, J. Inclusion Complexes of Non-Steroidal Anti-Inflammatory Drugs with Cyclodextrins: A Systematic Review. Biomolecules 2021, 11, 361. https:// doi.org/10.3390/biom11030361

Received: 28 January 2021

Accepted: 22 February 2021

Published: 27 February 2021

Publisher's Note: MDPI stays neutral with regard to jurisdictional claims in published maps and institutional affiliations.

Copyright: (c) 2021 by the authors. Licensee MDPI, Basel, Switzerland. This article is an open access article distributed under the terms and conditions of the Creative Commons Attribution (CC BY) license (https:/ / creativecommons.org/licenses/by/ $4.0 /)$.

\begin{abstract}
Non-steroidal anti-inflammatory drugs (NSAIDs) are one of the most widely used classes of medicines in the treatment of inflammation, fever, and pain. However, evidence has demonstrated that these drugs can induce significant toxicity. In the search for innovative strategies to overcome NSAID-related problems, the incorporation of drugs into cyclodextrins (CDs) has demonstrated promising results. This study aims to review the impact of cyclodextrin incorporation on the biopharmaceutical and pharmacological properties of non-steroidal anti-inflammatory drugs. A systematic search for papers published between 2010 and 2020 was carried out using the Preferred Reporting Items for Systematic Reviews and Meta-Analyses (PRISMA) protocol and the following search terms: "Complexation"; AND "Cyclodextrin"; AND "non-steroidal anti-inflammatory drug". A total of 24 different NSAIDs, 12 types of CDs, and 60 distinct inclusion complexes were identified, with meloxicam and $\beta-C D$ appearing in most studies. The results of the present review suggest that CDs are drug delivery systems capable of improving the pharmacological and biopharmaceutical properties of non-steroidal anti-inflammatory drugs.
\end{abstract}

Keywords: cyclodextrins; non-steroidal anti-inflammatory drugs; inclusion complexes

\section{Introduction}

Inflammation is the body's response to tissue damage, which aims to restore the integrity of the injured tissue through different mechanisms of induction, regulation, and resolution. Regardless of the aggressor stimulus, this response is essential for the restoration of homeostasis and, therefore, plays an important physiological role [1,2].

While inflammation is essential for the host defense against pathogens, it frequently occurs in the absence of infection, a phenomenon known as sterile inflammation [3,4]. Accordingly, despite the existence of efficient control mechanisms, failures in the resolution of inflammation often occur, which contributes significantly to the pathogenesis of several chronic diseases [5,6]. In these cases, the inflammatory response is the main cause of tissue injury and disease progression, besides contributing to the severity of other comorbidities $[7,8]$.

The classical therapeutic strategies for inflammatory diseases are mostly based on the use of anti-inflammatory drugs that act by either inhibiting the production of proinflammatory mediators or preventing the recruitment and activation of leukocytes at the inflammatory site $[9,10]$. In this context, non-steroidal anti-inflammatory drugs (NSAIDs) are one of the most widely used drug classes in the treatment of inflammation, fever, and pain. The mechanism of action underlying the anti-inflammatory, antipyretic, and 
analgesic effects of NSAIDs involves the inhibition of cyclooxygenases (COXs), enzymes that are critically responsible for the synthesis of prostaglandins, thromboxanes, and other prostanoids $[11,12]$. Prostaglandin $\mathrm{E}_{2}\left(\mathrm{PGE}_{2}\right)$ is produced in a wide variety of tissues, playing crucial roles in vasodilation and hyperalgesia in addition to interacting with proinflammatory cytokines that generate fever $[13,14]$. Thus, the mechanism of action of NSAIDs results in the inhibition of key clinical signs such as redness, warmth, pain, and swelling [2].

While non-selective NSAIDs inhibit both COX-1 and COX-2 isoforms, selective NSAIDs were developed to preferentially inhibit COX-2, which was expected to potentiate anti-inflammatory effects and reduce adverse effects. However, accumulating evidence has demonstrated that these drugs can induce significant toxicity [15]. Therefore, the development of innovative, safe, and effective anti-inflammatory drugs remains challenging [16].

In the search for innovative strategies to overcome NSAID-related problems, nanotechnology-based formulations have been developed to improve the pharmacokinetic properties of drugs as well as their interaction with their molecular targets. In this context, the incorporation of drugs into cyclodextrins represented a revolution in drug delivery systems $[17,18]$.

Cyclodextrins (CDs) are cyclic oligosaccharides formed by $\alpha$-D-glucopyranose units linked by $\alpha-1.4$ bonds, which contain a hydrophobic central cavity and a hydrophilic outer surface [19]. They are classified according to the number of glucopyranose units in $\alpha-C D, \beta-C D$, or $\gamma-C D$ as they present six, seven, and eight units, respectively. They may be presented as derivatives such as hydroxypropyl, methyl, di-methyl, sulfobutyl, and carboxymethyl CDs [20].

Among CDs, $\beta-C D$ presents the lowest water solubility, and despite presenting some intake restrictions [21], it is the most used CD mainly due to its easy production and lower price [19]. The characteristics of $\alpha-C D, \beta-C D$, and $\gamma-C D$ are summarized in Table 1.

Table 1. Physical and chemical properties of $\alpha-, \beta$ - and $\gamma$-cyclodextrin (CD).

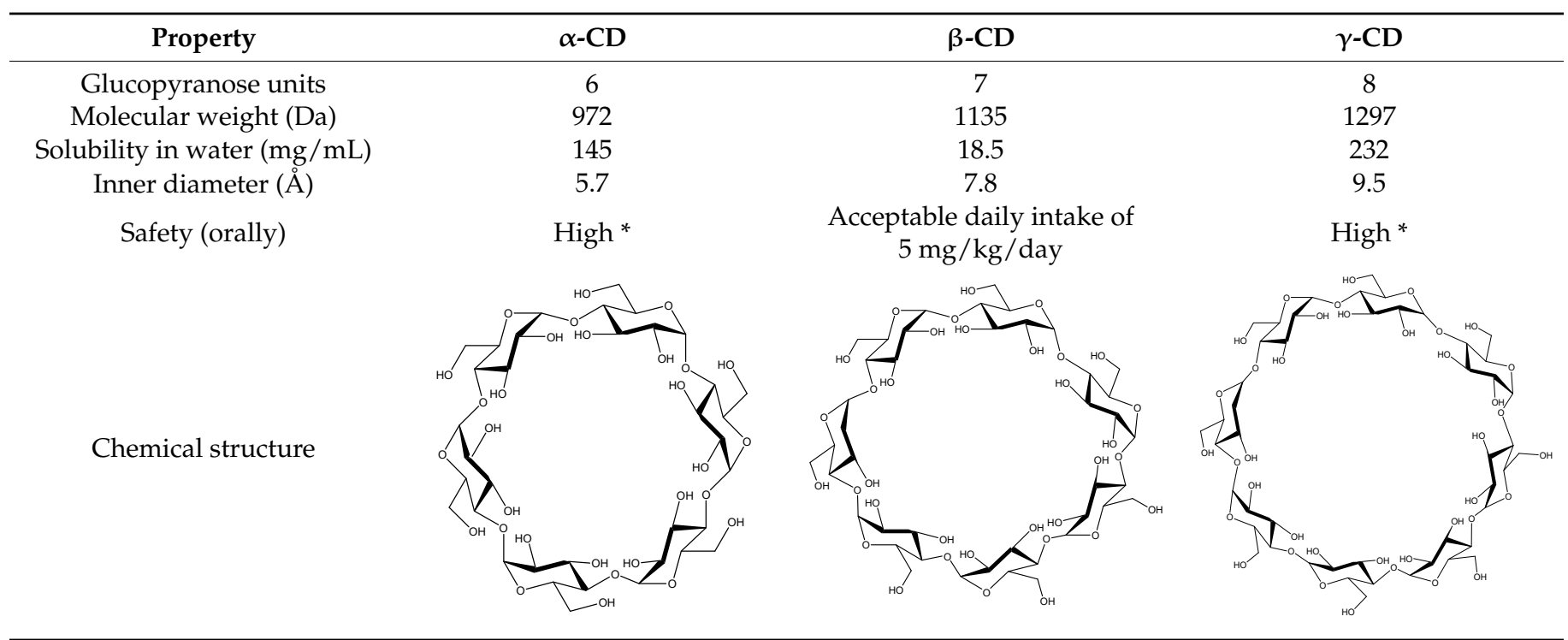

* According to the Regulatory Status of Cyclodextrins, they can be taken without restrictions [21].

Considering the importance of inclusion complexes in drug development, this study aims to review the impact of cyclodextrin incorporation on the biopharmaceutical and pharmacological properties of non-steroidal anti-inflammatory drugs.

\section{Methods}

The present study is a systematic review conducted in four scientific databases (Pubmed, Medline, Scopus, and EMBASE) according to the Preferred Reporting Items for Systematic 
Reviews and Meta-Analyses (PRISMA) protocol [22], using the following search terms: "Complexation"; AND “Cyclodextrin"; AND “Non-steroidal anti-inflammatory drug".

This search included all original articles addressing the impact of CD complexation on the biopharmaceutical and pharmacological effects of NSAIDs, published in the last decade (from 2010/01/01 to 2020/02/05, followed date of this study). The following inclusion criteria were adopted: (1) articles investigating inclusion complexes containing at least one CD and one NSAID in the same formulation; (2) articles analyzing the impact of the complexation on parameters directly related to the biological effects of the complexed NSAID; (3) articles with an analysis conducted in vivo, in vitro, ex vivo, in silico, or during clinical research. The exclusion criteria were the following: (1) studies demonstrating physicochemical characterization without pharmacological correlations; (2) studies investigating drugs with an NSAID-like mechanism of action without approval by drug regulatory agencies. Articles randomly found during the theoretical reference search which met the inclusion criteria were also included in the results.

Following the search on the selected databases and considering the randomly found articles, a total of 644 studies (Figure 1) were used for abstract reading, after which 553 articles were excluded as they did not meet the inclusion criteria. After full-text reading of the manuscripts, another 11 articles were excluded, totaling 80 articles selected to compose this review. The authors, type of inclusion complex, and main findings of these articles are summarized in Table 2. The Jeffrey Amazing Statistics Program (JASP) software version 0.9.2 for MacBook Pro 2010 [23] (Jasp Team, 2020) was used to determine the frequency of inclusion complexes, cyclodextrins, and NSAIDs reported in the studies. The data are expressed in pie charts (Figure 2) and the descriptive analysis is shown in the Supplementary Materials.

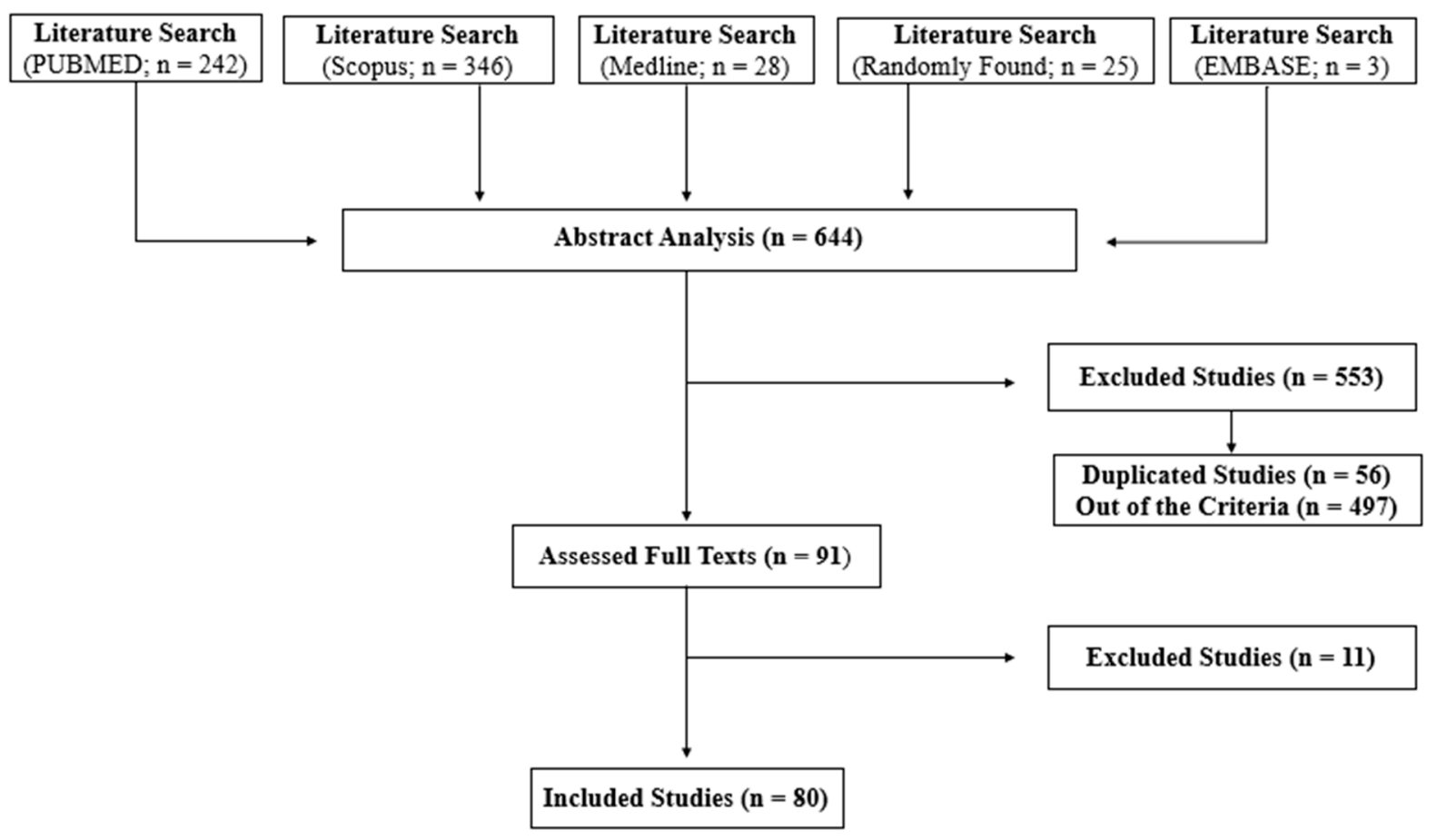

Figure 1. Schematic diagram showing the methodological strategy adopted in this systematic review. 


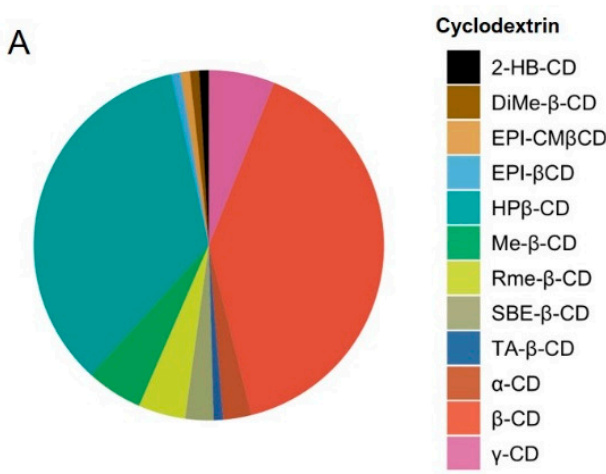

c

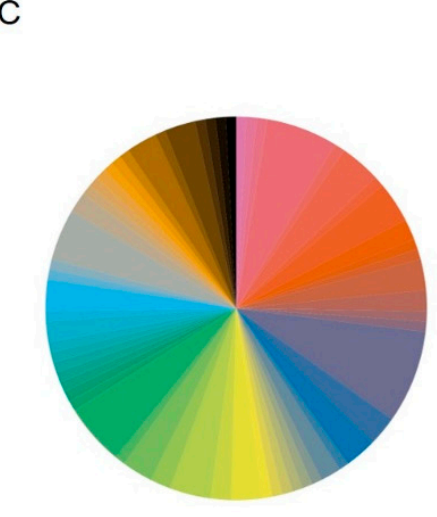

B

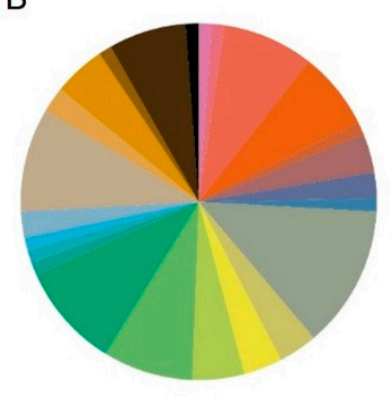

NSAID

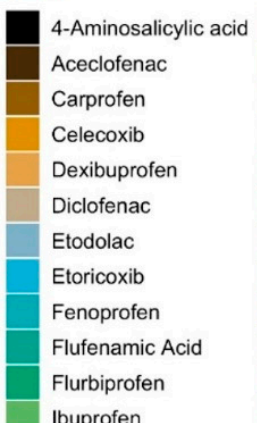

Indomethacin Ketoprofen Lornoxicam Meloxicam Mesalazine Naproxen Nepafenac Nimesulide Oxaprozin Piroxicam Sulindac Zaltoprofen
Inclusion complex

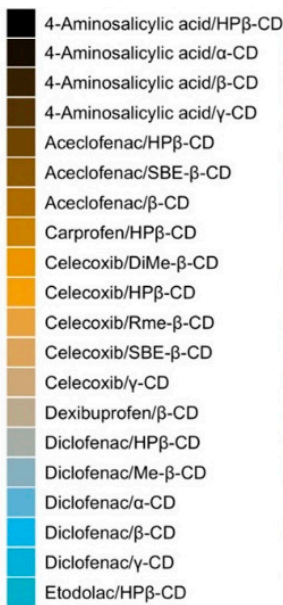

\begin{tabular}{|c|c|}
\hline Etodolac/Me- $\beta-C D$ & Ketoprofen/ $\beta-C D$ \\
\hline Etodolac/ $\beta-C D$ & Lornoxicam/HP $\beta$ - CD \\
\hline Etoricoxib/HPB-CD & Lornoxicam/3-CD \\
\hline Etoricoxib/B-CD & Meloxicam/HP $\beta-C D$ \\
\hline Fenoprofen/TA- $\beta-C D$ & Meloxicam $/ \beta-C D$ \\
\hline Flufenamic $A c i d / \beta-C D$ & Mesalazine/HP $\beta-C D$ \\
\hline Flurbiprofen/2-HB-CD & Naproxen/HP $\beta$-CD \\
\hline Flurbiprofen/HP $\beta-C D$ & Naproxen/ $\beta-C D$ \\
\hline Flurbiprofen/SBE- $\beta-C D$ & Nepafenac/HP $\beta-C D$ \\
\hline Flurbiprofen $/ \beta-C D$ & Nepafenac/Y-CD \\
\hline Ibuprofen/HPB-CD & Nimesulide/Me- $\beta-C D$ \\
\hline Ibuprofen/ $/$-CD & Oxaprozin/Me- $\beta-C D$ \\
\hline Ibuprofen/y-CD & Oxaprozin/Rme- $\beta$-CD \\
\hline Indomethacin/HP $\beta-C D$ & Oxaprozin/ $/$-CD \\
\hline Indomethacin/a-CD & Piroxicam/HP $\beta-C D$ \\
\hline Indomethacin/ $\beta-C D$ & Piroxicam/Me- $\beta-C D$ \\
\hline Indomethacin/y-CD & Piroxicam $/ \beta-C D$ \\
\hline Ketoprofen/EPI-CM $\beta C D$ & Sulindac/ $\beta-C D$ \\
\hline Ketoprofen/EPI- $\beta C D$ & Zaltoprofen/HP $\beta-C D$ \\
\hline Ketoprofen/HP $\beta-C D$ & Zaltoprofen/ $\beta-C D$ \\
\hline
\end{tabular}

Figure 2. Pie chart plots of frequency analysis. (A) Cyclodextrins; (B) non-steroidal anti-inflammatory drugs (NSAIDs); and (C) inclusion complexes. These data were analyzed using the Jeffrey Amazing Statistics Program (JASP) software version 0.9.2.

\section{Results}

A detailed analysis of the studies selected in the present review is shown in Table 2, while the analysis of frequency represented in pie charts is shown in Figure 2, and the descriptive analysis is detailed in the Supplementary Materials. We identified a total of 24 different NSAIDs used in inclusion complexes with cyclodextrins, including meloxicam $(\mathrm{n}=11 ; 12.94 \%)$, diclofenac $(\mathrm{n}=8 ; 9.41 \%)$, flurbiprofen $(\mathrm{n}=8 ; 9.41 \%)$, ibuprofen $(\mathrm{n}=7 ; 8.23 \%)$, piroxicam $(\mathrm{n}=7 ; 8.23 \%)$, aceclofenac $(\mathrm{n}=6 ; 7.05 \%)$, and oxaprozin $(\mathrm{n}=6 ; 7.05 \%)$ as the most frequently complexed drugs. Regarding the type of $\mathrm{CD}$, from a total of 12 different molecules, $\beta-\mathrm{CD}(40 \%)$ and HP- $\beta$-CD $(34.78 \%)$ were the cyclodextrins most used in the obtention of inclusion complexes with NSAIDs. According to the present frequency analysis, 60 distinct inclusion complexes were obtained and studied from the combination of the NSAIDs and CDs described above, including meloxicam $/ \beta-\mathrm{CD}(\mathrm{n}=9$; $7.82 \%)$, piroxicam $/ \beta-C D(n=7 ; 6.08)$, flurbiprofen $/ \mathrm{HP}-\beta-\mathrm{CD}(\mathrm{n}=6 ; 5.21 \%)$, ibuprofen $/ \beta$ $\mathrm{CD}(\mathrm{n}=4 ; 3.47 \%)$, oxaprozin/Rme- $\beta-\mathrm{CD}(\mathrm{n}=4 ; 3.47 \%)$, and piroxicam/HP- $\beta-\mathrm{CD}(\mathrm{n}=4$; $3.47 \%)$ as the most frequent inclusion complexes in the selected studies. 
Table 2. Summary of the studies addressing the impact of cyclodextrins on the biopharmaceutical and pharmacological properties of non-steroidal anti-inflammatory drugs.

\begin{tabular}{cr}
\hline Authors & Inclusion Complex \\
\hline & \\
& 4-Aminosalicylic acid $/ \alpha-$ \\
Lahiani-Skiba et al., 2011 [24] & $\mathrm{CD} / \beta-\mathrm{CD} / \gamma-\mathrm{CD} / \mathrm{HP}-\mathrm{CD}-\mathrm{C}$
\end{tabular}

Dahiya et al., 2015 [25]

Kasliwal et al., 2011 [26]

Li et al., 2014 [27]

Sharma et al., 2016 [28]

Samal et al., 2012 [29]

Ranpise et al., 2010 [30]

Parra et al., 2016 [31]

Cannavà et al., 2013 [32]

Mennini et al., 2012 [33]
Aceclofenac/HP- $\beta-\mathrm{CD}$

Aceclofenac/HP- $\beta-C D$

Aceclofenac/SBE- $\beta-C D$

Aceclofenac / $\beta$ CD/liposomes

Aceclofenac/ $\beta-C D$

Aceclofenac/ $\beta-\mathrm{CD} / \mathrm{HP}-\beta-$ $\mathrm{CD}$

Carprofen/HP- $\beta$-CD/PLGA nanoparticles

Celecoxib/PLGA/DiMe- $\beta$ CD.

Celecoxib/HP- $\beta$ CD/PVP/Chitosan-Ca ${ }^{2+}$ alginate
Study Design

Investigated the effect of

cyclodextrins on the solubility and chemical stability of 4-Aminosalicylic acid (in vitro).

Investigated the

pharmacokinetic parameters of immediate release aceclofenac tablets (in vitro and in vivo).

Formulated oral dispersible rapid-disintegration tablet to mask the bitter taste of aceclofenac (in vivo and in vitro).

Studied the dissolution profile of the inclusion complex and the controlled-release property of the drug (in vitro). Evaluated the improvement in stability and transdermal delivery to the inflammatory sites in osteoarthritis (ex vivo). Evaluated the solubility and dissolution rate of aceclofenac in complex with $\beta-C D$ (in vitro).

Developed formulations based on inclusion complexes of aceclofenac with $\beta-C D$ and HP- $\beta$-CD and evaluated their anti-inflammatory and analgesic effects (in vivo).

Characterized and analyzed the permeability (ex vivo),

biomechanical properties, skin irritation, and anti-inflammatory effects (in vivo) of the inclusion complex.

Evaluated the influence of the polymeric carriers on the pharmacological activity (ex vivo).

Developed a new system for colon delivery of celecoxib for systemic and local therapy (in vitro).
Main Findings

Complexation with different

CDs increased drug solubility, while $\gamma$-CD and HP- $\beta-C D$ significantly increased drug stability 4-fold.

Tablets prepared with HP- $\beta$-CD provided a more rapid onset of pharmacological effects in comparison to the market formulation and pure drug.

The formulated tablets tested in humans revealed considerable taste masking and rapid disintegration.

The formulation enhanced the dissolution profile of aceclofenac and promoted a controlled release of the drug. Achieved better stability permeation and enhanced skin bioavailability of the drug to epidermis and dermis. The dissolution rate of aceclofenac was significantly higher compared to pure aceclofenac.

Spray-dried aceclofenac complexed with $\beta-C D$

presented increased solubility.

The formulation presented stronger analgesic and anti-inflammatory effects when compared to the uncomplex drug.

The complex presented high membrane permeability and induced no evident skin irritation. Topically

administered nanoparticles demonstrated strong anti-inflammatory activity. Celecoxib-loaded PLGA/DiMe- $\beta$-CD microspheres were more effective than the free drug as an anti-inflammatory agent on human chondrocyte tests.

The results demonstrated the effectiveness of the proposed complex loaded in chitosan- $\mathrm{Ca}^{2+}$-alginate microspheres for colon delivery. 
Table 2. Cont.

\begin{tabular}{|c|c|c|}
\hline Authors & Inclusion Complex & Study Design \\
\hline Rescifina et al., 2019 [34] & Celecoxib/SBE- $\beta-C D$ & $\begin{array}{l}\text { Analyzed the cytotoxicity of } \\
\text { celecoxib and its inclusion } \\
\text { complex against A549 cell } \\
\text { lines and investigated the } \\
\text { impact of the combined use of } \\
\text { the inclusion complex in the } \\
\text { anti-cancer activity of } \\
\text { gemcitabine. }\end{array}$ \\
\hline
\end{tabular}

Jansook et al., 2018 [19]

Celecoxib $/ \gamma-C D /$ Rme- $\beta-C D$

Khalid et al., 2020 [35]

Khalid et al., 2017 [36]

Hamdan et al., 2016 [37]

Gan et al., 2016 [38]

Hamilton et al., 2018 [39]
Diclofenac/HP- $\beta-C D$

Diclofenac/HP- $\beta-C D$

Dexibuprofen $/ \beta-C D$

Dexibuprofen $/ \beta-C D$

Developed celecoxib eye drop formulations containing CD and evaluated drug bioavailability, mucoadhesion, permeability (ex vivo), and in vitro cytotoxicity to the retina cell line.

Prepared and investigated polymeric nanosponges of $\beta-C D$ to enhance the solubility of dexibuprofen (in vitro).

Prepared $\beta$-CD hydrogel nanoparticles using 2-

Acrylamido-2-methylpropane sulfonic acid and $\mathrm{N}$,

$\mathrm{N}^{\prime}$-Methylene bis(acrylamide).

Solubility was investigated

in vitro, and acute toxicity was investigated in rats (in vivo).

Evaluated effects of the preparation on drug absorption, bioavailability, and dissolution (in vivo and in vitro).

Examined the efficacy and cardiovascular safety of intravenous

HP- $\beta$-CD-diclofenac (clinical study).

Evaluated the pharmacokinetics of diclofenac and HP- $\beta-C D$ in

Diclofenac/HP- $\beta-C D$ patients with mild or
moderate renal insufficiency or mild hepatic impairment (clinical study).
Main Findings

Complexation increased the water solubility of celecoxib, which presented limited

cytotoxic activity against A549 cells. Complexation significantly increased the cytotoxic activity of this NSAID as well as improved the cytotoxicity of gemcitabine.

Formulations containing ternary celecoxib/Rme- $\beta$ -

$\mathrm{CD} /$ hyaluronic acid improved mucoadhesion, permeability through membrane barriers (semipermeable membrane, simulated vitreous humor, and scleral tissues), and cytocompatibility with human RPE cell line.

The polymeric complexation resulted in a 6-fold increase in dexibuprofen solubilization with $89 \%$ drug release within $30 \mathrm{~min}$.

The $\beta$-CD polymer hydrogel nanoparticles presented high solubility and excellent physicochemical characteristics. No evident toxicity was observed, indicating low oral toxicity.

In vivo experiments on rats showed that HP- $\beta-C D$ had no statistically significant effect on absorption or

bioavailability of diclofenac.

However, improvement in its in vitro dissolution by

HP- $\beta$-CD was observed.

The investigation suggested that the postoperative use of

HP- $\beta$-CD-diclofenac does not present any additional cardiovascular risk over the placebo.

The results suggest that diclofenac-HP- $\beta-C D$ might be administered to patients with mild or moderate renal insufficiency or mild hepatic impairment without requirement of dose adjustment. 
Table 2. Cont

\section{Authors}

Abdelkader et al., 2018 [40]

Klaewklod et al., 2015 [41]

Lenik et al., 2016 [42]

Mora et al., 2010 [43]

Vieira et al., 2013 [44]

Sherje et al., 2017 [45]

Ammar et al., 2013 [46]

Singh et al., 2011 [47]

\author{
Diclofenac $/ \alpha-C D, \beta-C D$, \\ $\gamma-\mathrm{CD}$, and $\mathrm{HP}-\beta-\mathrm{CD}$
}

Diclofenac/ $\beta$ $\mathrm{CD} / \mathrm{PEG} / \mathrm{K}_{2} \mathrm{CO}_{3}$

Diclofenac/HP- $\beta-C D$

Diclofenac/Me- $\beta-C D / M E A$

Diclofenac- $\beta-C D$

Etodolac/HP- $\beta-C D / L-$ arginine

Etodolac $/ \beta-\mathrm{CD} / \mathrm{Me}-\beta-$ $\mathrm{CD} / \mathrm{HP}-\beta-\mathrm{CD}$

Etoricoxib $/ \beta-\mathrm{CD} / \mathrm{HP}-\beta-\mathrm{CD}$
Study Design

Prepared inclusion complexes and evaluated for corneal permeation, corneal opacity/permeability, and toxicity (ex vivo).

Developed and evaluated the release (in vitro) and skin permeability (Franz diffusion cell method) of a diclofenac gel formulation containing $\beta-\mathrm{CD}$ and $\mathrm{K}_{2} \mathrm{CO}_{3}$ in PEG.

Evaluated taste-masking efficiency of diclofenac complexed with HP- $\beta$-CD and different sweeteners using a potentiometric electronic tongue.

Characterized

diclofenac-Me- $\beta-C D$ inclusion complex in the presence of MEA. Drug absorption was analyzed through excised human skin (ex vivo).

Analyzed the stability and colonic delivery of a

diclofenac- $\beta-C D$ conjugate in simulated gastric and small intestinal fluids, and in fecal human material.

Obtained, characterized, and evaluated, by computational modeling (in silico), the solubility of etodolac/HP- $\beta$-CD in the presence of different auxiliary agents.

Used several CDs to improve the physicochemical properties of etodolac through complexation (in vitro).

Developed, characterized, and evaluated the solubility and in vivo analgesic activity (tail flick and hot plate) of binary systems of etoricoxib with cyclodextrins.
Main Findings

Reduction in ocular toxicity by 3 - to 16-fold and comparable corneal permeability to free diclofenac were recorded using $\gamma-C D$ and HP- $\beta-C D$ complexes.

The release and permeation of diclofenac from the

formulation were significantly greater than those from a commercial gel, indicating its usefulness for the topical delivery of drugs.

Pronounced taste-masking effects were obtained with cyclodextrin, comparable to those obtained with other sweeteners such as acesulfame potassium and sodium saccharin.

Diclofenac solubility was increased by the addition of Me- $\beta-C D$ and further improved in the presence of MEA. Permeability through excised human skin was increased upon drug complexation.

The inclusion complex was stable in simulated gastric and small intestinal fluids, efficiently liberating diclofenac in less than $2 \mathrm{~h}$ within the human fecal slurry. More stable inclusion complexes were obtained when L-arginine was used as an auxiliary agent. The ternary complex of etodolac with HP- $\beta$-CD-L/Arginine improved the solubility of the NSAID.

Complexation to CDs enhanced the aqueous solubility and dissolution rate of etodolac.

Etoricoxib showed increased solubility and enhanced analgesic activity upon complexation with $\beta-C D$ and HP- $\beta-C D$.

Etoricoxib-HP- $\beta$-CD complex showed maximum analgesic effect. 
Table 2. Cont.

\begin{tabular}{|c|c|c|c|}
\hline Authors & Inclusion Complex & Study Design & Main Findings \\
\hline Ammar et al., 2017 [48] & Fenoprofen/TA- $\beta-C D$ & $\begin{array}{c}\text { Characterized and } \\
\text { investigated (in vivo) the } \\
\text { analgesic and } \\
\text { anti-inflammatory properties } \\
\text { of fenoprofen /TA- } \beta-C D \\
\text { inclusion complex conjugated } \\
\text { with other polymers. }\end{array}$ & $\begin{array}{c}\text { Fenoprofen calcium } \\
\text { dehydrate/TA- } \beta-C D \\
\text { conjugated with ethyl } \\
\text { cellulose polymer showed the } \\
\text { most potent and sustained } \\
\text { anti-inflammatory and } \\
\text { analgesic activities, possibly } \\
\text { due to controlled drug release. }\end{array}$ \\
\hline Alshehri et al., 2020 [49] & $\begin{array}{c}\text { Flufenamic } \\
\text { acid/ } \beta-C D / \text { Soluplus }{ }^{\circledR}\end{array}$ & $\begin{array}{l}\text { Investigated the solubility, } \\
\text { drug release profile (in vitro), } \\
\text { and in vivo anti-inflammatory } \\
\text { activity (carrageenan-induced } \\
\text { paw edema in rats) of the } \\
\text { inclusion complex. }\end{array}$ & $\begin{array}{l}\text { The solubility and } \\
\text { anti-inflammatory effect of } \\
\text { flurbiprofen were optimized } \\
\text { after incorporation into the } \\
\text { inclusion complex. }\end{array}$ \\
\hline Ishiguro et al., 2011 [50] & Flurbiprofen-2-HB-CD & $\begin{array}{l}\text { Prepared HB- } \beta \text {-CDs with } \\
\text { different degrees of } \\
\text { substitution and characterized } \\
\text { their physicochemical and } \\
\text { biological properties. The } \\
\text { hemolytic activity was } \\
\text { evaluated in vitro. }\end{array}$ & $\begin{array}{l}\text { HB- } \beta \text {-CDs acted as } \\
\text { fast-dissolving carrier } \\
\text { molecules for poorly } \\
\text { water-soluble drugs. The } \\
\text { hemolytic activity was } \\
\text { variable according to the } \\
\text { degree of substitution. }\end{array}$ \\
\hline Shinde et al., 2019 [51] & $\begin{array}{l}\text { Flurbiprofen/HP- } \\
\beta-C D / N-T M C\end{array}$ & $\begin{array}{c}\text { Analyzed TMC nanoparticles } \\
\text { containing } \\
\text { flurbiprofen/HP- } \beta-\mathrm{CD} \\
\text { inclusion complex for drug } \\
\text { release, mucoadhesion, and } \\
\text { irritation potential (in vitro). }\end{array}$ & $\begin{array}{l}\text { TMC nanoparticles offered } \\
\text { prolonged release potential for } \\
\text { transmucosal ocular delivery } \\
\text { of the NSAID. HET-CAM } \\
\text { studies demonstrated their } \\
\text { safety for ocular use. } \\
\text { Flurbiprofen/HP- } \beta-C D\end{array}$ \\
\hline Wang et al., 2017 [52] & Flurbiprofen/HP- $\beta-\mathrm{CD}$ & $\begin{array}{l}\text { Analyzed the impact of } \\
\text { penetration enhancers on } \\
\text { permeability (ex vivo) and } \\
\text { pharmacokinetics (in vivo) of } \\
\text { flurbiprofen formulations. }\end{array}$ & $\begin{array}{c}\text { percutaneous permeability } \\
\text { was significantly accelerated } \\
\text { by turpentine. In vivo } \\
\text { pharmacokinetic study } \\
\text { showed increased Cmax, } \\
\text { shortened Tmax, and } \\
\text { unchanged bioavailability. }\end{array}$ \\
\hline Vega et al., 2013 [53] & $\begin{array}{c}\text { Flurbiprofen/HP- } \beta- \\
\text { CD/PEG/PLGA }\end{array}$ & $\begin{array}{c}\text { Prepared formulations and } \\
\text { evaluated as skin-controlled } \\
\text { delivery systems (in vivo and } \\
\text { ex vivo). }\end{array}$ & $\begin{array}{l}\text { Greater anti-inflammatory } \\
\text { efficacy compared to the } \\
\text { control and stronger efficacy } \\
\text { in preparations using } \\
\text { HP- } \beta-C D \text {. }\end{array}$ \\
\hline Li et al., 2010 [54] & Flurbiprofen $/ \beta-C D$ & $\begin{array}{l}\text { Evaluated the effect of a drug } \\
\text { solution containing a } \\
\text { surfactant and } \beta-C D \text { on the } \\
\text { solubility, bioavailability, and } \\
\text { pharmacokinetics of } \\
\text { flurbiprofen. }\end{array}$ & $\begin{array}{c}\text { Solubility and plasma } \\
\text { exposure (both AUC and } \\
\text { Cmax) of flurbiprofen in the } \\
\text { mixed system were } \\
\text { significantly higher compared } \\
\text { to formulations containing } \\
\text { surfactant alone, or } \beta-C D \\
\text { alone. }\end{array}$ \\
\hline Zhang et al., 2015 [55] & $\begin{array}{c}\text { Flurbiprofen } / \beta-C D, H P- \\
\beta-C D \text { and SBE- } \\
\beta-C D / \text { liposomes }\end{array}$ & $\begin{array}{c}\text { Characterized the } \\
\text { pharmacokinetic profile } \\
\text { (in vivo) of inclusion } \\
\text { complexes of the NSAID and } \\
\beta-C D, H P-\beta-C D \text {, and } \\
\text { SBE- } \beta-C D \text { loaded into } \\
\text { liposomes. }\end{array}$ & $\begin{array}{l}\text { The delivery systems } \\
\text { significantly improved the } \\
\text { relative bioavailability of } \\
\text { flurbiprofen in Wistar rats, } \\
\text { indicating that they are } \\
\text { promising delivery systems } \\
\text { for poorly soluble drugs. }\end{array}$ \\
\hline
\end{tabular}


Table 2. Cont

\begin{tabular}{|c|c|c|c|}
\hline Authors & Inclusion Complex & Study Design & Main Findings \\
\hline Zhao et al., 2013 [56] & Flurbiprofen $/ \beta-C D$ & $\begin{array}{c}\text { Incorporated } \\
\text { flurbiprofen } / \beta-C D \text { into PACA } \\
\text { nanoparticles and its oral } \\
\text { bioavailability was evaluated } \\
\text { in rats (in vivo). }\end{array}$ & $\begin{array}{l}\text { The reduced particle size and } \\
\text { increased surface area may } \\
\text { have contributed to the } \\
\text { enhanced oral bioavailability } \\
\text { of flurbiprofen in the new } \\
\text { formulation. } \\
\text { Ibuprofen-HP- } \beta-C D\end{array}$ \\
\hline Celebioglu et al., 2019 [57] & Ibuprofen/HP- $\beta-C D$ & $\begin{array}{l}\text { Produced and characterized } \\
\text { ibuprofen-HP- } \beta-C D \\
\text { nanofibrous webs and } \\
\text { investigated their solubility in } \\
\text { water and artificial saliva. }\end{array}$ & $\begin{array}{l}\text { nanofibrous webs presented } \\
\text { excellent solubility in both } \\
\text { water and artificial saliva, } \\
\text { indicating that they have the } \\
\text { potential to be used as } \\
\text { fast-dissolving oral drug } \\
\text { delivery systems. }\end{array}$ \\
\hline Volkova et al., 2020 [58] & Ibuprofen $/ \beta-C D$ & $\begin{array}{c}\text { Prepared and evaluated } \\
\text { ibuprofen properties in MOFs } \\
\text { based on } \beta-C D \text { and } \mathrm{K}^{+} \\
\text {(in vitro). }\end{array}$ & $\begin{array}{l}\text { Ibuprofen- } \beta-C D \text { inclusion } \\
\text { complex showed improved } \\
\text { aqueous solubility. }\end{array}$ \\
\hline Rehman et al., 2013 [59] & Ibuprofen $/ \beta-C D$ & $\begin{array}{l}\text { Prepared tablets containing } \\
\text { variable compositions of } \\
\text { polysaccharide matrix and } \\
\text { assessed for in vitro drug } \\
\text { release in simulated } \\
\text { gastrointestinal fluids } \\
\text { containing digestive enzymes. }\end{array}$ & $\begin{array}{l}\text { Formulations containing ethyl } \\
\text { cellulose and } \beta-C D(1: 1) \\
\text { presented better drug release } \\
\text { profiles and proved to be the } \\
\text { most adequate for drug } \\
\text { delivery to the colon. }\end{array}$ \\
\hline Marianecci et al., 2013 [60] & Ibuprofen $/ \beta-C D$ & $\begin{array}{l}\text { Evaluated the permeation } \\
\text { properties of ibuprofen- } \beta-C D \\
\text { loaded into non-ionic } \\
\text { surfactant vesicles (NSVs) } \\
\text { using a two-compartment } \\
\text { diffusion cell (in vitro). }\end{array}$ & $\begin{array}{l}\text { Ibuprofen- } \beta \text {-CD-NSV system } \\
\text { exhibited significantly } \\
\text { improved in vitro drug } \\
\text { permeation properties with } \\
\text { respect to those of the plain } \\
\text { drug suspension. }\end{array}$ \\
\hline Li et al., 2017 [61] & Ibuprofen $/ \gamma-\mathrm{CD} / \mathrm{MOF} / \mathrm{PAA}$ & $\begin{array}{l}\text { Prepared and characterized } \\
\text { composites of } \gamma \text {-CD-based } \\
\text { MOFs and PAA. The in vitro } \\
\text { cytotoxicity was evaluated } \\
\text { using J774 macrophages. }\end{array}$ & $\begin{array}{l}\text { Microspheres composed of } \\
\text { CD-MOF nanocrystals } \\
\text { embedded in PAA exhibited } \\
\text { sustained drug release and } \\
\text { presented reduced cell toxicity, } \\
\text { compared with pure drug or } \\
\text { the drug- } \gamma \text {-CD complex. }\end{array}$ \\
\hline Hartlieb et al., 2017 [62] & Ibuprofen- $\gamma-\mathrm{CD}-\mathrm{MOF}$ & $\begin{array}{l}\text { Obtained and characterized a } \\
\text { pharmaceutical cocrystal of } \\
\text { ibuprofen-MOF-CD. } \\
\text { Cytotoxicity (in vitro) and } \\
\text { pharmacokinetics (in vivo) } \\
\text { were determined. }\end{array}$ & $\begin{array}{l}\text { The pharmaceutical cocrystal } \\
\text { did not affect viability of the } \\
\text { cells, while the in vivo } \\
\text { bioavailability was not } \\
\text { affected, and the formulation } \\
\text { presented } 100 \% \text { longer } \\
\text { half-life in blood plasma. } \\
\text { NSAID solubility was }\end{array}$ \\
\hline Felton et al., 2014 [63] & $\begin{array}{c}\text { Ibuprofen, ketoprofen, } \\
\text { naproxen, flurbiprofen } / \beta \text { - } \\
\text { CD/HP- } \beta-C D\end{array}$ & $\begin{array}{l}\text { Characterized the properties } \\
\text { of different NSAIDs } \\
\text { complexed with } \beta-C D \text { and } \\
\text { two HP- } \beta-C D \text { derivatives (in } \\
\text { silico). }\end{array}$ & $\begin{array}{c}\text { significantly increased with } \\
\text { increasing CD concentration } \\
\text { of both HP- } \beta-C D \text { derivatives, } \\
\text { whereas } \beta-C D \text { complexation } \\
\text { caused little increase in } \\
\text { NSAID solubility. }\end{array}$ \\
\hline Mohamed et al., 2011 [64] & Indomethacin $/ \mathrm{HP}-\beta-\mathrm{CD}$ & $\begin{array}{l}\text { Investigated the influence of } \\
\text { CD incorporation on the } \\
\text { solubility pharmacologic } \\
\text { effect of indomethacin in } \\
\text { injured eyes of albino rabbits } \\
\text { (in vivo). }\end{array}$ & $\begin{array}{l}\text { The complex demonstrated } \\
\text { sufficient solubility and } \\
\text { effectiveness in healing the } \\
\text { corneal lesion, with improved } \\
\text { anti-inflammatory activity. }\end{array}$ \\
\hline
\end{tabular}


Table 2. Cont.

\begin{tabular}{cc}
\hline Authors & Inclusion Complex \\
\hline Ribeiro-Rama et al., 2011 [65] & Indomethacin/HP- $\beta$-CD \\
Vranic et al., 2010 [66] & \\
Indomethacin $/ \alpha-C D / \gamma-C D$ \\
Kirri et al., 2012 [67] \\
Ketoprofen $/$ Epi- $\beta-C D / E p-C D$
\end{tabular}

Grecu et al., 2014 [68]

Moutasim et al., 2017 [69]

Ammar et al., 2012 [70]

Bramhane et al., 2011 [71]

Samprasit et al., 2018 [72]

Samprasit et al., 2014 [73]
Lornoxicam $/ \beta-C D / H P-\beta-C D$

Lornoxicam / $\beta-C D / L-$ arginine

Meloxicam/HP- $\beta-C D$

Meloxicam/HP- $\beta-C D$
Study Design

Investigated the hepatic and renal injuries caused by indomethacin in several formulations including complexes with HP- $\beta-\mathrm{CD}$ (in vivo).

The aim of the study was to compare the dissolution profiles of indomethacin alone and complexed with CDs.

Developed a topical administration system to improve the solubility of ketoprofen.

Compared the anti-inflammatory effects of orally administered ketoprofen and ketoprofen $/ \beta-C D$ inclusion complex using two models of experimentally induced acute inflammation in rats (paw edema and peritonitis).

Formulated tablets containing lornoxicam- $\beta-C D$ to increase drug solubility and to mask its bitter taste. Bioequivalence was evaluated in healthy volunteers.

Analyzed the efficacy of lornoxicam by complexation with cyclodextrins in liquid crystalline gel (ex vivo).

Evaluated the dissolution of lornoxicam molecular inclusion with $\beta-C D$ alone and in combination with arginine (in vitro).

Prepared taste-masked meloxicam oral dissolving films and evaluated in human volunteers. Cytotoxicity was evaluated using human gingival fibroblasts (HGF).

Developed and characterized oral disintegrating tablets using the combination of ion exchange resin and CD.

Solubility (in vitro) and taste (in vivo) were evaluated.
Main Findings

The animals administered with indomethacin in complexed form showed similar hepatic and renal lesions to those administered with the drug in acid or salt forms.

The complexation of indomethacin with $\alpha$ - and $\gamma$-cyclodextrins resulted in increased dissolution rates.

Demonstrated the usefulness of this new system, with improvement in the dissolution of the drug. The complexation of ketoprofen with $\beta-C D$ resulted in increased solubility and bioavailability compared with ketoprofen. In both models of inflammation, ketoprofen $/ \beta-C D$ complex presented a stronger anti-inflammatory activity than ketoprofen.

The formulation presented acceptable palatability,

enhanced dissolution, and rapid onset of drug action.

The pharmacokinetic profile was significantly different from the control tablet.

The preparation showed high improvement in drug dissolution, superior anti-inflammatory activity, and low skin permeation, being suitable for topical use. The complexation of lornoxicam with $\beta-C D$ and arginine resulted in significantly higher dissolution compared with the uncomplexed drug and binary systems.

A fast disintegration time of meloxicam was obtained from ethanol system, which presented lower cytotoxicity. The films rapidly dissolved in the mouth and had a less bitter taste than meloxicam. Meloxicam incorporated in a combination of ion exchange resin and $\mathrm{HP}-\beta-\mathrm{CD}$

demonstrated a good taste, rapid disintegration, complete solubility, and significant stability. 
Table 2. Cont

\begin{tabular}{|c|c|c|c|}
\hline Authors & Inclusion Complex & Study Design & Main Findings \\
\hline Rein et al., 2020 [74] & Meloxicam $/ \beta-C D$ & $\begin{array}{l}\text { Investigated an in situ } \\
\text { forming system based on } \\
\text { meloxicam in } \beta-C D \text { for } \\
\text { periodontitis treatment, } \\
\text { aiming sustainable drug } \\
\text { release at a periodontal pocket } \\
\text { (in vitro). }\end{array}$ & $\begin{array}{l}\text { The developed system } \\
\text { comprising } 40 \% \beta-C D \\
\text { transformed into } \\
\text { microparticles extended the } \\
\text { drug release to } 7 \text { days in the } \\
\text { locality of the treatment. }\end{array}$ \\
\hline Jafar et al., 2017 [75] & Meloxicam- $\beta$-CD-TEA & $\begin{array}{l}\text { Investigated the properties of } \\
\text { a buoyant in situ gel prepared } \\
\text { from a ternary complex of } \\
\text { meloxicam with } \beta-C D \text { and } \\
\text { TEA on solubility, stability, } \\
\text { and in vivo anti-inflammatory } \\
\text { activity (carrageenan model in } \\
\text { mice). }\end{array}$ & $\begin{array}{l}\text { The solubility, stability. and } \\
\text { anti-inflammatory activity of } \\
\text { meloxicam was successfully } \\
\text { increased due to its } \\
\text { incorporation in ternary } \\
\text { complex with } \beta \text {-CD-TEA, } \\
\text { demonstrating improved } \\
\text { pharmaceutical and } \\
\text { pharmacodynamic properties. }\end{array}$ \\
\hline Ainurofiq et al., 2016 [76] & Meloxicam/ $\beta$-CD & $\begin{array}{c}\text { Investigated inclusion } \\
\text { complexes of } \\
\text { meloxicam } / \beta-\mathrm{CD} \\
\text { incorporated into orally } \\
\text { disintegrating tablets using a } \\
\text { quality by design approach. }\end{array}$ & $\begin{array}{l}\text { Although interactions } \\
\text { between meloxicam and } \beta-C D \\
\text { occurred under different } \\
\text { complexation methods, best } \\
\text { solubility and dissolution rate } \\
\text { enhancement was achieved } \\
\text { with the spray drying method. }\end{array}$ \\
\hline Shende et al., 2015 [77] & $\begin{array}{c}\text { Meloxicam } / \beta-C D \text {-based } \\
\text { nanosponges }\end{array}$ & $\begin{array}{c}\text { Investigated inclusion } \\
\text { complexes of meloxicam and } \\
\beta-C D-\text { based nanosponges on } \\
\text { stability, solubility, drug } \\
\text { release (in vitro and in vivo) } \\
\text { and analgesic and } \\
\text { anti-inflammatory effect } \\
\text { (in vivo). }\end{array}$ & $\begin{array}{l}\text { Incorporation of meloxicam } \\
\text { into } \beta \text {-CD-based nanosponges } \\
\text { improved its } \\
\text { biopharmaceutical properties } \\
\text { and potentiated its analgesic } \\
\text { and anti-inflammatory effects. }\end{array}$ \\
\hline Radia et al., 2012 [78] & Meloxicam/ $\beta$-CD. & $\begin{array}{l}\text { Investigated the effect of } \\
\text { Meloxicam complexation with } \\
\beta-C D \text { on the bioavailability of } \\
\text { the drug (in vivo and } \\
\text { in vitro). }\end{array}$ & $\begin{array}{c}\text { The oral bioavailability of ML } \\
\text { was significantly improved } \\
\text { through complexation with } \\
\beta-C D \text {. }\end{array}$ \\
\hline Rasool et al., 2011 [79] & Meloxicam $/ \beta-C D$ & $\begin{array}{l}\text { Developed and evaluated the } \\
\text { properties of a meloxicam } \\
\text { transdermal gel in } \\
\text { complexation with } \beta-C D \text {. }\end{array}$ & $\begin{array}{c}\text { The dissolution properties of } \\
\text { the meloxicam- } \beta-C D \\
\text { complexes were superior } \\
\text { when compared to meloxicam } \\
\text { alone. }\end{array}$ \\
\hline Awasthi et al., 2011 [80] & Meloxicam $/ \beta-C D$ & $\begin{array}{c}\text { Investigated the improvement } \\
\text { on meloxicam solubility by } \\
\text { preparation of its solid } \\
\text { dispersion using } \beta-C D \\
\text { blended with various } \\
\text { water-soluble polymer } \\
\text { carriers (in vitro). }\end{array}$ & $\begin{array}{c}\text { Meloxicam formulations } \\
\text { obtained by solid dispersion } \\
\text { technique presented } \\
\text { significantly enhanced } \\
\text { solubility, highlighting } \beta-C D \\
\text { blended with } 0.12 \%(\mathrm{w} / \mathrm{w}) \\
\text { HP-methylcellulose polymer. }\end{array}$ \\
\hline Janovský et al., 2010 [81] & Meloxicam $/ \beta-C D$ & $\begin{array}{l}\text { Investigated the influence on } \\
\text { analgesic activity and serum } \\
\text { levels after meloxicam } \\
\text { complexation (in vivo). }\end{array}$ & $\begin{array}{l}\text { Stronger analgesic activity } \\
\text { than unmodified meloxicam; } \\
\text { Serum levels of meloxicam } \\
\text { were significantly higher. } \\
\text { The solubility of both drugs }\end{array}$ \\
\hline Samprasit et al., 2013 [82] & $\begin{array}{c}\text { Meloxicam, Piroxicam / } \beta-C D \text {, } \\
\text { HP- } \beta-C D\end{array}$ & $\begin{array}{l}\text { Prepared and characterized } \\
\text { inclusion complexes of } \\
\text { NSAIDs with either } \beta-C D \text { or } \\
\text { HP- } \beta-C D \text { loaded into an } \\
\text { anionic exchange resin. }\end{array}$ & $\begin{array}{l}\text { was found to increase with } \\
\text { increasing CD concentration. } \\
\text { The presence of cyclodextrin } \\
\text { in the loading solution } \\
\text { resulted in the improvement } \\
\text { of drug loading into the resin. }\end{array}$ \\
\hline
\end{tabular}


Table 2. Cont

\begin{tabular}{|c|c|c|c|}
\hline Authors & Inclusion Complex & Study Design & Main Findings \\
\hline Tang et al., 2018 [83] & $\begin{array}{l}\text { Mesalazine/HP- } \beta \text { - } \\
\mathrm{CD} / \text { chitosan } \\
\text { nanoparticles }\end{array}$ & $\begin{array}{l}\text { Analyzed the cytotoxic and } \\
\text { anti-inflammatory effects of } \\
\text { mesalazine/HP- } \beta \text { - } \\
\text { CD/chitosan nanoparticles on } \\
\text { cytokine stimulated HT-29 } \\
\text { cells (in vitro). }\end{array}$ & $\begin{array}{l}\text { The complexed drug more } \\
\text { strongly inhibited the } \\
\text { production of inflammatory } \\
\text { mediators such as NO, PGE } 2 \\
\text { and IL-8. }\end{array}$ \\
\hline Elkordy et al., 2012 [84] & $\begin{array}{l}\text { Naproxen } / \beta-C D, \\
\text { Poloxamer-407 }\end{array}$ & $\begin{array}{l}\text { Investigated the effects of } \\
\beta-C D, \text { Poloxamer- } 407 \text { and } \\
\text { sorbitol as drug carriers } \\
\text { (in vitro). }\end{array}$ & $\begin{array}{l}\text { Different tested mixtures of } \\
\text { the drug with } \beta-C D \text { and } \\
\text { Poloxamer- } 407 \text { showed } \\
\text { enhancement in drug release. } \\
\text { The formulation showed a }\end{array}$ \\
\hline Shelley et al., 2018 (a) [85] & Nepafenac/HP- $\beta-C D$ & $\begin{array}{l}\text { Investigated trans-corneal } \\
\text { permeation of nepafenac in a } \\
\text { HP- } \beta \text {-CD complex (ex vivo). }\end{array}$ & $\begin{array}{l}\text { significantly higher drug } \\
\text { concentration in the cornea } \\
\text { with a permeation rate } 18 \text {-fold } \\
\text { higher than the commercial } \\
\text { product. }\end{array}$ \\
\hline Shelley et al., 2018 (b) [86] & Nepafenac/HP- $\beta-C D$. & $\begin{array}{l}\text { Evaluated the solubility and } \\
\text { transcorneal permeation of a } \\
\text { gel containing } \\
\text { nepafenac-HP- } \beta-C D \text {, in } \\
\text { comparison with the } \\
\text { commercial nepafenac (ex } \\
\text { vivo). }\end{array}$ & $\begin{array}{c}\text { The formulation increased the } \\
\text { solubility and ocular release } \\
\text { of nepafenac, resulting in a } \\
\text { higher concentration of drug } \\
\text { in the cornea, sclera and retina } \\
\text { compared to the commercial } \\
\text { drug }\end{array}$ \\
\hline Lorenzo-Veiga et al., 2020 [87] & Nepafenac $/ \gamma-C D / H P-\beta-C D$ & $\begin{array}{l}\text { Analyzed CD-based } \\
\text { formulations with several } \\
\text { polymers to efficiently deliver } \\
\text { nepafenac topically to the eye } \\
\text { (in vitro and ex vivo). }\end{array}$ & $\begin{array}{c}\text { Formulations with } \\
\text { methylcellulose and } \\
\text { carboxymethylcellulose } \\
\text { polymers showed improved } \\
\text { solubility, mucoadhesion, } \\
\text { permeability and } \\
\text { anti-inflammatory potential. }\end{array}$ \\
\hline Auda, 2014 [88] & Nimesulide/Me- $\beta$-CD & $\begin{array}{l}\text { Characterized and evaluated } \\
\text { the solubility (in vitro) and } \\
\text { the anti-inflammatory effect of } \\
\text { the inclusion complex in } \\
\text { carrageenan-induced } \\
\text { inflammation in rats (in vivo). } \\
\text { Used a combined approach }\end{array}$ & $\begin{array}{l}\text { The study showed that the } \\
\text { inclusion system enhanced the } \\
\text { solubility and } \\
\text { anti-inflammatory activity of } \\
\text { the drug. }\end{array}$ \\
\hline Mura et al., 2016 [89] & Oxaprozin/Me- $\beta-\mathrm{CD}$ & $\begin{array}{l}\text { based on drug complexation } \\
\text { with methylated } \beta-C D \text { and } \\
\text { nanoclays to improve the } \\
\text { dissolution of oxaprozin } \\
\text { (in vitro). }\end{array}$ & $\begin{array}{c}\text { The complexation and clay } \\
\text { nanoencapsulation improved } \\
\text { the oxaprozin dissolution } \\
\text { properties around } 100 \% .\end{array}$ \\
\hline Maestrelli et al., 2011 [90] & $\begin{array}{l}\text { Oxaprozin-Rme- } \beta- \\
\text { D/chitosan/bile } \\
\text { components }\end{array}$ & $\begin{array}{l}\text { Investigated the effect of the } \\
\text { combined use of Rme- } \beta-C D, \\
\text { chitosan, and different bile } \\
\text { components on solubility and } \\
\text { permeability of oxaprozin } \\
\text { through Caco- } 2 \text { cells. }\end{array}$ & $\begin{array}{l}\text { Chitosan and bile acids } \\
\text { increased the Rme- } \beta-C D \\
\text { solubilizing power. The } \\
\text { addition of CS to } \\
\text { oxaprozin-Rme- } \beta \text {-CD systems } \\
\text { increased drug permeability } \\
\text { through Caco- } 2 \text { cells. }\end{array}$ \\
\hline Maestrelli et al., 2017 [91] & $\begin{array}{l}\text { Oxaprozin } / \text { Rme- } \beta-\mathrm{CD} / \mathrm{L}- \\
\text { arginine }\end{array}$ & $\begin{array}{c}\text { Investigated a possible } \\
\text { enhancement of the } \\
\text { Rme- } \beta \text {-CD solubilizing } \\
\text { efficacy through a combined } \\
\text { approach with arginine in } \\
\text { sepiolite nanoclay (SV). } \\
\text { Anti-inflammatory activity } \\
\text { was assessed using } \\
\text { CFA-induced arthritis } \\
\text { (in vivo). }\end{array}$ & $\begin{array}{l}\text { The new hybrid } \\
\text { nanocomposite was more } \\
\text { effective than the respective } \\
\text { oxaprozin-Rme- } \beta \text {-CD and } \\
\text { oxaprozin-SV systems in } \\
\text { improving the drug } \\
\text { dissolution properties, as well } \\
\text { as the effects on CFA-induced } \\
\text { arthritis. }\end{array}$ \\
\hline
\end{tabular}


Table 2. Cont.

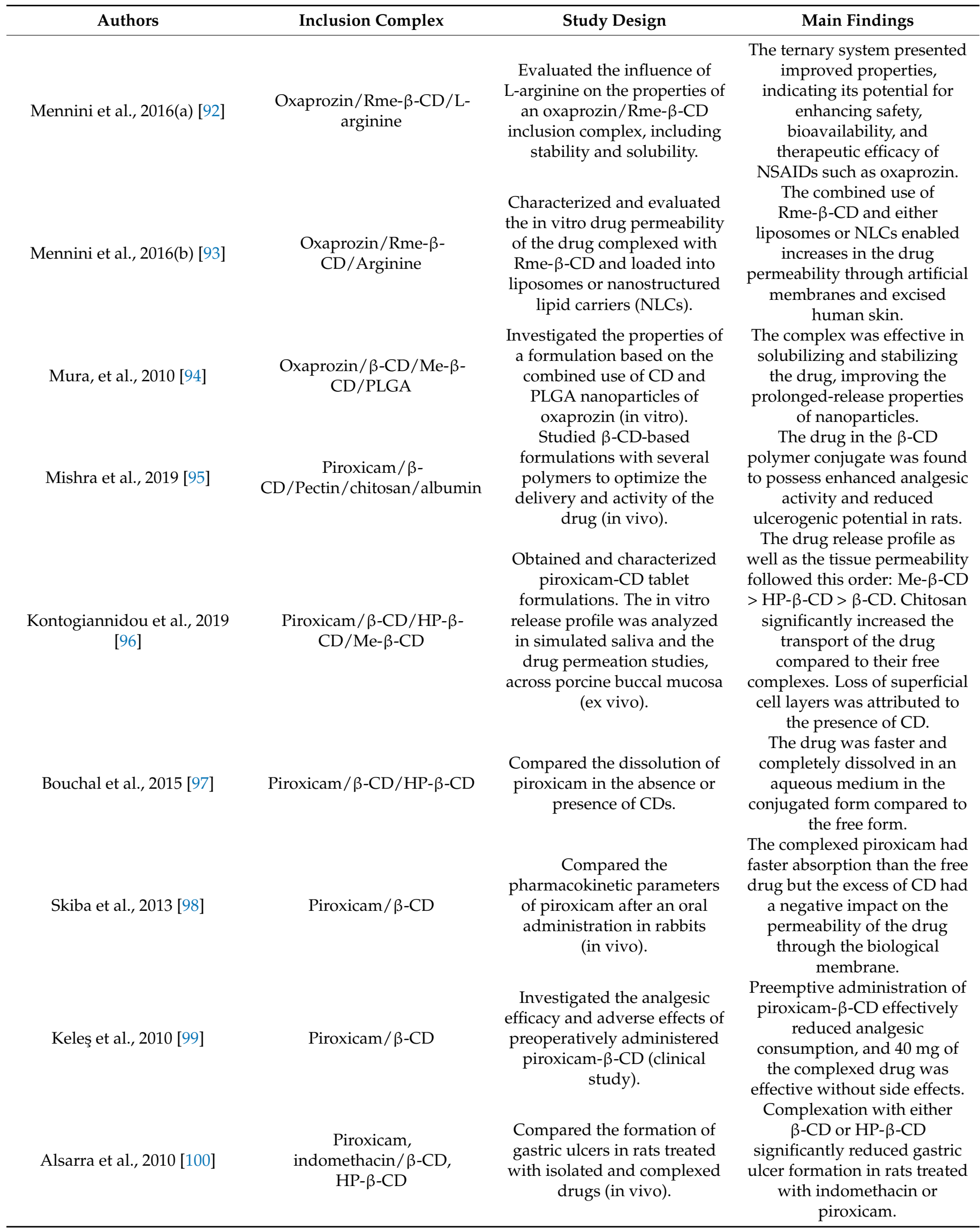


Table 2. Cont.

\begin{tabular}{|c|c|c|c|}
\hline Authors & Inclusion Complex & Study Design & Main Findings \\
\hline Haggag et al., 2016 [101] & Sulindac/ $\beta-C D / C A P$ & $\begin{array}{c}\text { Characterized and } \\
\text { investigated the ability of } \\
\text { different polymers to } \\
\text { ameliorate sulindac-induced } \\
\text { gastric ulcers in rats (in vivo). }\end{array}$ & $\begin{array}{l}\beta-C D \text { significantly enhanced } \\
\text { the solubility of sulindac but } \\
\text { had no protective effect } \\
\text { against gastric ulcer formation } \\
\text { in rats. }\end{array}$ \\
\hline Sherje et al., 2018 [102] & $\begin{array}{l}\text { Zaltoprofen } / \beta-\mathrm{CD} / \mathrm{HP}-\beta \text { - } \\
\text { CD/L-arginine }\end{array}$ & $\begin{array}{l}\text { Investigated formulations } \\
\text { containing CDs and } \\
\text { L-arginine for drug stability, } \\
\text { dissolution, and solubility } \\
\text { (in vitro). }\end{array}$ & $\begin{array}{l}\text { The addition of L-arginine to } \\
\text { drug-CD system increased } \\
\text { stability, dissolution, and } \\
\text { solubility of zaltoprofen. }\end{array}$ \\
\hline
\end{tabular}

Abbreviations: Cyclodextrin (CD); Hydroxypropyl- $\beta$-Cyclodextrin (HP- $\beta-C D)$; Beta cyclodextrin ( $\beta$-CD); Sulfobutyl ether- $\beta$-cyclodextrin (SBE- $\beta$-CD); Alpha cyclodextrin $(\alpha-\mathrm{CD})$; Gamma cyclodextrin ( $\gamma$-CD); Methyl- $\beta$-cyclodextrin (Me- $\beta$-CD); Polyethylene glycol (PEG); Poly(lactic-co-glycolic acid) (PLGA); Polyvinylpyrrolidone (PVP); Dimethyl- $\beta$-Cyclodextrin (DiMe- $\beta$-CD); hydroxypropyl methylcellulose (HP-methylcellulose); $\beta$-CD-Epichlorohydrin polymer (EPI- $\beta$-CD); Carboxymethylated- $\beta$-CD-epichlorohydrin polymer (EPI-CM$\beta-\mathrm{CD})$; Soluplus ${ }^{\circledR}$ (supramolecular ternary inclusion complex); Metal-organic frameworks (MOFs); Potassium (K ${ }^{+}$); Non-steroidal anti-inflammatory drug (NSAID); Randomly methylated- $\beta-C D$ (Rme- $\beta-C D) ;$ Meloxicam (ML); Nitric oxide (NO); Prostaglandin E-2 (PGE 2 ); Retinal pigment epithelium (RPE); Nanostructured lipid carriers (NLCs); Potassium carbonate $\left(\mathrm{K}_{2} \mathrm{CO}_{3}\right)$; Hen's Egg Test chorioallantoic membrane (HET-CAM); Complete Freund's adjuvant (CFA)-induced; Maximum concentration (Cmax); Time maximum (Tmax); Area under the curve (AUC); Triethanolamine (TEA); Sepiolite nanoclay (SV); Human gingival fibroblast (HGF); N-trimethyl chitosan (TMC); Polyacrylic acid (PAA); Non-ionic surfactant vesicles (NSVs); Monoethanolamine (MEA); Poly(Alkyl-Cyanocrylate) (PACA); Cellulose acetate phthalate (CAP); Interleukin-8 (IL-8); Triacetyl (TA).

\section{Discussion}

In a worldwide context, significant concern has arisen regarding the efficacy and safety of the currently available anti-inflammatory drugs [103]. There have been specific conditions in which they are either not effective or can cause significant side effects [104,105]. Therefore, strategies aiming to improve the safety and efficacy of NSAIDs, such as CD preparations, have a cornerstone impact on anti-inflammatory therapy.

Consistent evidence has demonstrated that cyclodextrins can form complexes with both organic and inorganic compounds and, therefore, have become widely used in the food, pharmaceutical, and cosmetic industries. These molecules can be used as functional excipients able to prevent volatility, increase stability, solubility, and membrane permeation, and improve organoleptic characteristics of many molecules [106,107]. Importantly, evidence has demonstrated that CDs are promising drug delivery systems for several drugs, improving their physicochemical and biopharmaceutical properties, increasing their bioavailability, and reducing toxicity, which has a significant impact on the pharmacological effects of both synthetic and naturally occurring compounds [108].

The three-dimensional conformation of glucopyranose units in the CD macrocyclic structures places the hydrophobic carbon backbones facing the inner part of the cone, providing the hydrophobic characteristic of the cavity. This structural arrangement determines the application of CDs as host structures to form inclusion complexes with diverse poorly water-soluble molecules such as NSAIDs [109]. Additionally, structural changes in the CD structure by the substitution of chemical groups (such as acetyl, hydroxypropyl, dimethyl, and sulphate) have a significant impact on solubility and drug-release properties of the delivery system [110].

In this study, $\beta-C D$ was the most frequently used native cyclodextrin, while hydroxypropyl $\beta-C D$ was the principal synthetic $C D$ derivative addressed in the manuscripts, which is probably due to the easy production and low cost of this naturally occurring molecule. However, compared to $\alpha$ - and $\gamma$-CDs, $\beta$-CD has the lowest solubility, and its acceptable daily intake is up to a dose of $5 \mathrm{mg} / \mathrm{kg} /$ day [21]. Thus, although CDs are generally recognized as safe, exposure to higher doses of $\beta-C D$ can lead to toxicity, as highlighted in the study by Kontogiannidou et al. [96], which attributed the loss of superficial cell layers of porcine buccal mucosa to $\beta-C D$ and its synthetic derivatives. According to Ishiguro et al. [50], the cytotoxicity (hemolytic activity) of flurbiprofen-2-HB-CD inclusion 
complexes with different degrees of substitution depends on the degree of substitution. Moreover, consistent evidence has demonstrated the safety of the use of $\beta$-CD-based formulations both in vitro [51] and in vivo [36]. Importantly, a study by Rescifina et al. [34] in 2019 demonstrated that the complexation of celecoxib with SBE- $\beta$-CD significantly increased the cytotoxic activity of this NSAID, in addition to potentiating the cytotoxicity of gemcitabine, demonstrating enhanced anti-cancer activity.

The development of pharmacological effects depends on adequate drug concentration reaching the aimed tissue. Plasma and other aqueous fluids perfuse most tissues in the body; thus, solubilization in aqueous fluids is often required for drug effectiveness [111]. In contrast, to be absorbed from the application site to the blood or to other tissues, the active compound needs to leave the aqueous phase and permeate lipidic membranes [112] (Lennernas, 2014), and therefore, a balance between lipophilicity and hydrophilicity is desirable for a drug candidate [113]. Thereby, solubility and permeability are considered as key aspects to achieve adequate drug bioavailability and pharmacological effect [114].

Following this principle, several studies included in the present review used cyclodextrins (especially $\beta-C D$ and $H P-\beta-C D$ ) to improve the water solubility and increase the bioavailability of NSAIDs such as aceclofenac [29], meloxicam [80], flurbiprofen [54], diclofenac [37], and lornoxicam. It is worth mentioning that increased solubility was associated with improved bioavailability [37,54] and anti-inflammatory activity [70]. In general, NSAIDs are acidic lipophilic compounds characterized by the presence of an aromatic ring bearing an acidic moiety and can differ in their lipophilicities based on their aryl structure and substituents. For instance, the Log P (octanol-water partition coefficient) values for sodium diclofenac, ibuprofen, piroxicam, and paracetamol are 4.51, 3.97, 1.8, and 0.31, respectively [115]. Sodium diclofenac, ibuprofen, and piroxicam are classified as class II drugs and paracetamol as class III according to the Biopharmaceutics Classification System [116,117]. Considering that most NSAID preparations aim for systemic distribution, the development of pharmaceutical formulations based on $\mathrm{CD}$ inclusion complexes may be a promising strategy to reverse their low solubility $[117,118]$.

The local or topical administration of drugs in the skin or other membranes is an interesting alternative to the oral route, decreasing systemic side effects and avoiding firstpass metabolism [119]. Topical and transdermal drug administration may show advantages compared to oral administration, especially when a regional effect is expected due the possibility of drug application close to the action site, e.g., deeper skin layers, muscles, and blood vessels [120]. In this context, many studies have investigated the effect of CD complexation (in both binary and ternary systems) on the permeation properties of NSAIDs such as aceclofenac [28], diclofenac [40,41], celecoxib [19], and nepafenac [86]. Regarding formulations designed for ocular administration, aqueous solubility in biological fluid as well as lipophilicity to ensure the membrane permeation are also required characteristics to achieved pharmacological effects [121]. Abdelkader and colleagues [40] showed that $\alpha-C D, \beta-C D, \gamma-C D$, and HP- $\beta$-CD had little effect on the ocular permeability of diclofenac, although the toxicity of this drug was significantly reduced by association with $\gamma-C D$ and HP- $\beta$-CD. On the other hand, celecoxib $/ \gamma-\mathrm{CD} / \mathrm{Rme}-\beta-\mathrm{CD}[19]$ and nepafenac $/ \mathrm{HP}-\beta-$ $\mathrm{CD}$ [86] showed excellent corneal permeability, resulting in increased drug concentration in the cornea, sclera, and retina, demonstrating the relevance of cyclodextrins as drug delivery systems in ocular formulations.

Cyclodextrin-complexed drugs have demonstrated improved pharmacokinetics aspects, resulting in greater efficacy and safety [108]. In a study by Dahiya and collaborators [25], the incorporation of HP- $\beta$-cyclodextrin provided a more rapid onset of pharmacological effects of aceclofenac in comparison to the market formulation and pure drug. Importantly, a clinical study using a diclofenac-HP- $\beta-C D$ formulation in patients with mild or moderate renal insufficiency or mild hepatic impairment indicated its safe use without the requirement of dose adjustment [39]. Moreover, evidence has indicated that $\beta-C D$, HP- $\beta-C D$, and SBE- $\beta-C D$ can be successfully used to improve the pharmacokinetic profile of flurbiprofen, indicating that they are promising delivery systems for poorly soluble 
drugs [52,55]. An interesting approach has been investigated by Hartlieb et al. (2017). A pharmaceutical preparation of ibuprofen-MOF-CD exhibited similar in vivo bioavailability and uptake in blood plasma as pure ibuprofen. However, the complexed samples showed a significant increase in the blood half-life of ibuprofen when compared to the pure drug, pointing out that the pharmacokinetic aspect improvement may change according to the pharmaceutical preparation. Their results suggested that ibuprofen-MOF-CD may be an effective delivery vehicle able to produce extended analgesic effects. Another interesting use of CDs to avoid drug passage through the blood-brain barrier has been described by Wang et al. [122].

To evaluate the effectiveness of cyclodextrins in improving the pharmacological effects of NSAIDs, several studies investigated the anti-inflammatory and analgesic properties of different NSAID-CD inclusion complexes, as these drugs have fundamental importance in the management of inflammation and pain. On the other hand, these drugs can present significant side effects, such as increased cardiovascular risk and stimulation of gastric ulcer formation [121]. Grecu and collaborators [68] demonstrated that ketoprofen/ $\beta$-CD complex presented a stronger anti-inflammatory activity than ketoprofen pure in rat models of paw edema and peritonitis. Similar findings were obtained by Auda [88], Alshehri et al. [123], and Ammar et al. [70] using inclusion complexes of nimesulide-Me- $\beta-C D$, flufenamic acid- $\beta-C D$, and lornoxicam- $\beta-C D /$ lornoxicam-HP- $\beta-C D$, respectively. The impact of $C D$ incorporation on the anti-inflammatory effects of NSAIDs has been further demonstrated in vitro and was associated with inhibition of inflammatory mediator production [32,83].

According to Singh et al. [47], etoricoxib, a selective COX-2 inhibitor, presented increased solubility and enhanced analgesic activity upon complexation with $\beta-\mathrm{CD}$ and $\mathrm{HP}-\beta-\mathrm{CD}$, exhibiting maximum analgesic effects when complexed to HP- $\beta-C D$. The incorporation of meloxicam [77] or aceclofenac [30] to $\beta-C D$ was found to significantly improve the biopharmaceutical properties and potentiate the analgesic and anti-inflammatory effects of these NSAIDs in vivo. Accordingly, a clinical study demonstrated that piroxicam had its analgesic activity potentiated by incorporation with $\beta-C D$ [99]. Furthermore, evidence has indicated that this complexation may result in significantly reduced ulcerogenic potential [95]. This finding is corroborated with studies addressing the ulcerogenic potential of NSAIDs complexed with cyclodextrins, which showed that complexation with either $\beta-C D$ or HP- $\beta-C D$ significantly reduced gastric ulcer formation in rats treated with indomethacin or piroxicam, as shown in Table 2 . Additionally, a clinical study conducted by Gan et al. [38] demonstrated the cardiovascular safety of intravenous HP- $\beta$-CD-diclofenac. On the other hand, $\beta$-CD significantly enhanced the solubility of sulindac but had no protective effect against gastric ulcer formation in rats [101]. The authors discuss that the reported non-effect is related to sulindac itself, which is characterized by its greater ability for gastrointestinal adhesion and high accumulation that can induce gastric ulcer [101].

Cyclodextrin-based inclusion complexes have proven their usefulness to improve the stability [124] and taste of oral pharmaceutical forms, resulting in improved patient compliance in addition to contributing to the biopharmaceutical properties of oral drugs [107]. Accordingly, this study showed that incorporation of cyclodextrins (such as $\alpha-, \beta-, \gamma_{-}$, and HP- $\beta-C D$ ) had a positive impact on the stability of NSAIDs $[24,28,102]$ as well as demonstrated the potential to be used as taste-masking excipients [26,42,69,72].

The use of CDs can be limited depending on the drug structure and the CD structure and size. The guest molecules need to interact by non-covalent bonding and fit totally or partially within the CD cavity. The main aspects to ensure proper complexation are related to the chemical structure and physicochemical properties of the guest and host molecules [31,45]. Several studies have used NSAID-CD inclusion complexes as part of ternary and quaternary systems in association with a wide variety of compounds and nanoparticles (e.g., liposomes, chitosan, L-arginine, and poly (lactic-co-glycolic acid) (PLGA)) to achieve additional improvement of the physicochemical, biopharmaceutical, and pharmacological properties. It has been shown that water-soluble polymers such as 
PLGA, polyethylene glycol (PEG), and HP-methylcellulose, among others, can reduce CD mobility and increase the complex solubility $[31,43,45,48,51,61,82,90,92]$.

Sherje et al. achieved a relevant increase in the solubility of etodolac using a ternary system with HP- $\beta-C D$ and L-arginine. It has been described that basic amino acids such as L-arginine can complex with the drug and the $\mathrm{CD}$ by hydrogen bonding, electrostatic interactions, and salt formation. The amphiphilic characteristic of $\mathrm{L}$-arginine allows the structure to interact its hydrophobic region with the hydrophobic portion of $\mathrm{HP}-\beta-\mathrm{CD}$, resulting in a supramolecular ternary complex $[45,71]$. The findings of the present systematic review indicate that ternary and quaternary systems may contribute to the effectiveness of some NSAID-CD complexes by promoting better complexation, solubility, and a more controlled drug release.

\section{Conclusions}

The results from this review suggest that cyclodextrins, including 2-HB-CD, DiMe$\beta-C D$, EPI-CM- $\beta$-CD, EPI- $\beta-C D$, HP- $\beta-C D$, Me- $\beta-C D$, Rme- $\beta-C D$, SBE- $\beta-C D$, TA- $\beta-C D$, $\alpha-C D, \beta-C D$, and $\gamma-C D$, can be successfully employed in the obtention of inclusion complexes with NSAIDs such as meloxicam, diclofenac, and flurbiprofen, the most frequently complexed drugs.

While the effectiveness of different cyclodextrins in improving the biopharmaceutical and pharmacological properties of NSAIDs depends on both the complexed drug and the type of $C D$, an overall analysis of the studies included in the present review showed that drug characteristics, including solubility, stability, taste, toxicity, and bioavailability, in addition to the expected anti-inflammatory and analgesic activity were found to be improved upon complexation with molecules such as $\beta-C D$ and HP- $\beta-C D$, the most frequently used CDs.

In conclusion, the findings of the present systematic review suggest that cyclodextrins are promising drug delivery systems capable of improving the pharmacological and biopharmaceutical properties of non-steroidal anti-inflammatory drugs.

Supplementary Materials: The following are available online at https:/ /www.mdpi.com/2218-273 X/11/3/361/s1, Figure S1: Publication Year, Table S1: Frequencies for Publication Year, Table S2: Frequencies for NSAID, Table S3: Frequencies for Cyclodextrin, Table S4: Frequencies for Complexation.

Author Contributions: Conceptualization, J.R.-F.; search, selection, and analysis, G.M.M., J.R.B., Y.C.F.T., V.O.R.eS., J.R.B., and J.R-F; writing of the manuscript, G.M.M., J.R.B., Y.C.F.T., S.C.M.A.Y., and J.R.-F.; critical review, M.S.G. and S.C.M.A.Y. All authors have read and agreed to the published version of the manuscript.

Funding: This study received no external funding.

Acknowledgments: The authors would like to thank the Instituto Gonçalo Moniz (Fiocruz-BA) for the support of this publication.

Conflicts of Interest: The authors declare no conflict of interest.

\section{References}

1. Medzhitov, R. Origin and physiological roles of inflammation. Nature 2008, 454, 428-435. [CrossRef]

2. Netea, M.G.; Balkwill, F.; Chonchol, M.; Cominelli, F.; Donath, M.Y.; Giamarellos-Bourboulis, E.J.; Golenbock, D.; Gresnigt, M.S.; Heneka, M.T.; Hoffman, H.M.; et al. A guiding map for inflammation. Nat. Immunol. 2017, 18, 826-831. [CrossRef] [PubMed]

3. Chen, G.Y.; Nuñez, G. Sterile inflammation: Sensing and reacting to damage. Nat. Rev. Immunol. 2010, 10, 826-837. [CrossRef]

4. Gong, T.; Liu, L.; Jiang, W.; Zhou, R. DAMP-sensing receptors in sterile inflammation and inflammatory diseases. Nat. Rev. Immunol. 2020, 20, 95-112. [CrossRef] [PubMed]

5. Nathan, C.; Ding, A. Nonresolving Inflammation. Cell 2010, 140, 871-882. [CrossRef] [PubMed]

6. Furman, D.; Campisi, J.; Verdin, E.; Carrera-Bastos, P.; Targ, S.; Franceschi, C.; Ferrucci, L.; Gilroy, D.W.; Fasano, A.; Miller, G.W.; et al. Chronic inflammation in the etiology of disease across the life span. Nat. Med. 2019, 25, 1822-1832. [CrossRef]

7. Medzhitov, R. Inflammation 2010: New Adventures of an Old Flame. Cell 2010, 140, 771-776. [CrossRef]

8. Ptaschinski, C.; Lukacs, N.W. Acute and Chronic Inflammation Induces Disease Pathogenesis, 2nd ed.; Elsevier: Amsterdam, The Netherlands, 2018. [CrossRef] 
9. Straub, R.H.; Cutolo, M. Glucocorticoids and chronic inflammation. Rheumatology 2016, 55, ii6-ii14. [CrossRef] [PubMed]

10. Yeung, Y.T.; Aziz, F.; Guerrero-Castilla, A.; Arguelles, S. Signaling Pathways in Inflammation and Anti-inflammatory Therapies. Curr. Pharm. Des. 2018, 24, 1449-1484. [CrossRef]

11. Wongrakpanich, S.; Wongrakpanich, A.; Melhado, K.; Rangaswami, J. A Comprehensive Review of Non-Steroidal AntiInflammatory Drug Use in The Elderly. Aging Dis. 2018, 9, 143-150. [CrossRef] [PubMed]

12. Theken, K.N. Variability in analgesic response to non-steroidal anti-inflammatory drugs. Prostaglandins Other Lipid Mediat. 2018, 139, 63-70. [CrossRef] [PubMed]

13. Kawahara, K.; Hohjoh, H.; Inazumi, T.; Tsuchiya, S.; Sugimoto, Y. Prostaglandin E2-induced inflammation: Relevance of prostaglandin E receptors. Biochim. Biophys. Acta (BBA)-Mol. Cell Biol. Lipids 2015, 1851, 414-421. [CrossRef] [PubMed]

14. Tsuge, K.; Inazumi, T.; Shimamoto, A.; Sugimoto, Y. Molecular mechanisms underlying prostaglandin E2-exacerbated inflammation and immune diseases. Int. Immunol. 2019, 31, 597-606. [CrossRef]

15. Arias, L.H.M.; González, A.M.; Fadrique, R.S.; Vazquez, E.S. Cardiovascular Risk of Nonsteroidal Anti-inflammatory Drugs and Classical and Selective Cyclooxygenase-2 Inhibitors: A Meta-analysis of Observational Studies. J. Clin. Pharmacol. 2019, 59, 55-73. [CrossRef]

16. Alessandri, A.L.; Sousa, L.P.; Lucas, C.D.; Rossi, A.G.; Pinho, V.; Teixeira, M.M. Resolution of inflammation: Mechanisms and opportunity for drug development. Pharmacol. Ther. 2013, 139, 189-212. [CrossRef]

17. Lakkakula, J.R.; Krause, R.W.M. A vision for cyclodextrin nanoparticles in drug delivery systems and pharmaceutical applications. Nanomed. 2014, 9, 877-894. [CrossRef]

18. Haimhoffer, Á.; Rusznyák, Á.; Réti-Nagy, K.; Vasvári, G.; Váradi, J.; Vecsernyés, M.; Bácskay, I.; Fehér, P.; Ujhelyi, Z.; Fenyvesi, F.; et al. Cyclodextrins in Drug Delivery Systems and Their Effects on Biological Barriers. Sci. Pharm. 2019, 87, 33. [CrossRef]

19. Jansook, P.; Ogawa, N.; Loftsson, T. Cyclodextrins: Structure, physicochemical properties and pharmaceutical applications. Int. J. Pharm. 2018, 535, 272-284. [CrossRef]

20. Crini, G. Review: A History of Cyclodextrins. Chem. Rev. 2014, 114, 10940-10975. [CrossRef]

21. Braga, S.S. Cyclodextrins: Emerging Medicines of the New Millennium. Biomolecules 2019, 9, 801. [CrossRef]

22. Moher, D.; Liberati, A.; Tetzlaff, J.; Altman, D.G.; The PRISMA Group. Preferred reporting items for systematic reviews and meta-analyses: The PRISMA statement. PLoS Med. 2009, 6, e1000097. [CrossRef]

23. JASP, T. JASP (Version 0.12. 2) [computer Software]; Eric-Jan Wagenmakers, University of Amsterdam: Amsterdam, The Netherlands, 2020.

24. Lahiani-Skiba, M.; Youm, I.; Bounoure, F.; Skiba, M. Improvement in the water solubility and stability of 4ASA by the use of cyclodextrins. J. Incl. Phenom. Macrocycl. Chem. 2010, 69, 327-331. [CrossRef]

25. Dahiya, S.; Kaushik, A.; Pathak, K. Improved Pharmacokinetics of Aceclofenac Immediate Release Tablets Incorporating ist Inclusion Complex with Hydroxypropyl- $\beta$-Cyclodextrin. Sci. Pharm. 2015, 83, 501-510. [CrossRef]

26. Kasliwal, N.; Negi, J.S. Development, characterization and performance evaluation of oro-dispersible tablet containing aceclofenac hydroxypropyl- $\beta$-cyclodextrin binary system. J. Incl. Phenom. Macrocycl. Chem. 2011, 71, 215-224. [CrossRef]

27. Li, S.; Zhang, T.; Xiao, M.; Zhang, Z.; Li, W.; Bai, J. Intercalation of Aceclofenac/Sulfobutyl Ether- $\beta$-cyclodextrin Complex into Layered Double Hydroxides through Swelling/Restoration Reaction and Its Controlled-Release Properties. J. Nanomater. 2014, 2014, 1-7. [CrossRef]

28. Sharma, G.; Kaur, M.; Raza, K.; Thakur, K.; Katare, O.P. Aceclofenac- $\beta$-cyclodextrin-vesicles: A dual carrier approach for skin with enhanced stability, efficacy and dermatokinetic profile. RSC Adv. 2016, 6, 20713-20727. [CrossRef]

29. Samal, H.B.; Debata, J.; Naveen Kumar, N.; Sneha, S.; Patra, P.K. Solubility and dissolution improvement of Aceclofenac using BCyclodextrin. Int. J. Drug Dev. Res. 2012, 1, 39-43.

30. Ranpise, N.S.; Kulkarni, N.S.; Mair, P.D.; Ranade, A.N. Improvement of water solubility and in vitro dissolution rate of aceclofenac by complexation with $\beta$-cyclodextrin and hydroxypropyl- $\beta$-cyclodextrin. Pharm. Dev. Technol. 2010, 15, 64-70. [CrossRef]

31. Parra, A.; Clares, B.; Rosselló, A.; Garduño-Ramírez, M.L.; Abrego, G.; García, M.L.; Calpena, A.C. Ex vivo permeation of carprofen from nanoparticles: A comprehensive study through human, porcine and bovine skin as anti-inflammatory agent. Int. J. Pharm. 2016, 501, 10-17. [CrossRef]

32. Cannavà, C.; Tommasini, S.; Stancanelli, R.; Cardile, V.; Cilurzo, F.; Giannone, I.; Puglisi, G.; Ventura, C.A. Celecoxib-loaded PLGA/cyclodextrin microspheres: Characterization and evaluation of anti-inflammatory activity on human chondrocyte cultures. Colloids Surf. B Biointerfaces 2013, 111, 289-296. [CrossRef] [PubMed]

33. Mennini, N.; Furlanetto, S.; Cirri, M.; Mura, P. Quality by design approach for developing chitosan-Ca-alginate microspheres for colon delivery of celecoxib-hydroxypropyl- $\beta$-cyclodextrin-PVP complex. Eur. J. Pharm. Biopharm. 2012, 80, 67-75. [CrossRef]

34. Rescifina, A.; Surdo, E.; Cardile, V.; Avola, R.; Graziano, A.C.E.; Stancanelli, R.; Tommasini, S.; Pistarà, V.; Ventura, C.A. Gemcitabine anticancer activity enhancement by water soluble celecoxib/sulfobutyl ether- $\beta$-cyclodextrin inclusion complex. Carbohydr. Polym. 2019, 206, 792-800. [CrossRef]

35. Khalid, Q.; Ahmad, M.; Minhas, M.U.; Batool, F.; Malik, N.S.; Rehman, M. Novel $\beta$-cyclodextrin nanosponges by chain growth condensation for solubility enhancement of dexibuprofen: Characterization and acute oral toxicity studies. J. Drug Deliv. Sci. Technol. 2021, 61, 102089. [CrossRef]

36. Khalid, Q.; Ahmad, M.; Minhas, M.U. Synthesis of $\beta$-cyclodextrin hydrogel nanoparticles for improving the solubility of dexibuprofen: Characterization and toxicity evaluation. Drug Dev. Ind. Pharm. 2017, 43, 1873-1884. [CrossRef] 
37. Hamdan, I.I.; El-Sabawi, D.; Jalil, M.A. Potential interaction between zinc ions and a cyclodextrin-based diclofenac formulation. Drug Dev. Ind. Pharm. 2016, 42, 418-428. [CrossRef] [PubMed]

38. Gan, T.J.; Singla, N.; Daniels, S.E.; Lacouture, P.G.; Min, L.H.; Reyes, C.R.; Carr, D.B. Cardiovascular safety of hydroxypropyl- $\beta$ cyclodextrin-diclofenac in the management of acute postsurgical pain: A pooled analysis of 2 randomized, double-blind, placeboand active comparator-controlled phase III clinical trials. J. Clin. Anesth. 2016, 31, 249-258. [CrossRef]

39. Hamilton, D.A.; Ernst, C.C.; Kramer, W.G.; Madden, D.; Lang, E.; Liao, E.; Lacouture, P.G.; Ramaiya, A.; Carr, D.B. Pharmacoki-

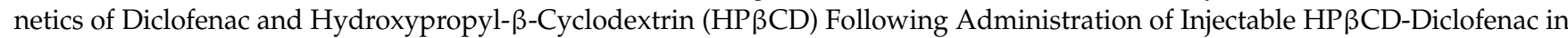
Subjects with Mild to Moderate Renal Insufficiency or Mild Hepatic Impairment. Clin. Pharmacol. Drug Dev. 2017, 7, 110-122. [CrossRef] [PubMed]

40. Abdelkader, H.; Fathalla, Z.; Moharram, H.; Ali, T.F.S.; Pierscionek, B. Cyclodextrin Enhances Corneal Tolerability and Reduces Ocular Toxicity Caused by Diclofenac. Oxidative Med. Cell. Longev. 2018, 2018, 5260976. [CrossRef]

41. Klaewklod, A.; Tantishaiyakul, V.; Hirun, N.; Sangfai, T.; Li, L. Characterization of supramolecular gels based on $\beta$-cyclodextrin and polyethyleneglycol and their potential use for topical drug delivery. Mater. Sci. Eng. C 2015, 50, 242-250. [CrossRef]

42. Lenik, J.; Wesoły, M.; Ciosek, P.; Wróblewski, W. Evaluation of taste masking effect of diclofenac using sweeteners and cyclodextrin by a potentiometric electronic tongue. J. Electroanal. Chem. 2016, 780, 153-159. [CrossRef]

43. Mora, M.J.; Longhi, M.R.; Granero, G.E. Synthesis and characterization of binary and ternary complexes of diclofenac with a methyl- $\beta-C D$ and monoethanolamine and in vitro transdermal evaluation. Eur. J. Med. Chem. 2010, 45, 4079-4088. [CrossRef]

44. Vieira, A.C.; Serra, A.C.; Carvalho, R.A.; Gonsalves, A.; Figueiras, A.; Veiga, F.J.; Basit, A.W.; Gonsalves, A.M.D.R. Microwave synthesis and in vitro stability of diclofenac- $\beta$-cyclodextrin conjugate for colon delivery. Carbohydr. Polym. 2013, 93, 512-517. [CrossRef]

45. Sherje, A.P.; Kulkarni, V.; Murahari, M.; Nayak, U.Y.; Bhat, P.; Suvarna, V.; Dravyakar, B. Inclusion Complexation of Etodolac with Hydroxypropyl-beta-cyclodextrin and Auxiliary Agents: Formulation Characterization and Molecular Modeling Studies. Mol. Pharm. 2017, 14, 1231-1242. [CrossRef]

46. Ammar, H.O.; Ghorab, M.; Mostafa, D.M.; Makram, T.S.; Ali, R.M. Host-guest system of etodolac in native and modified $\beta$-cyclodextrins: Preparation and physicochemical characterization. J. Incl. Phenom. Macrocycl. Chem. 2012, 77, 121-134. [CrossRef]

47. Singh, I.; Kumar, P.; Pahuja, S.; Tung, V.; Arora, S. Development and pharmacological evaluation of cyclodextrin complexes of etoricoxib. Acta Pol. Pharm.-Drug Res. 2011, 68, 279-284.

48. Ammar, H.O.; Makram, T.S.; Mosallam, S. Effect of Polymers on the Physicochemical Properties and Biological Performance of Fenoprofen Calcium Dihydrate-Triacetyl- $\beta$-Cyclodextrin Complex. Pharmaceutics 2017, 9, 23. [CrossRef] [PubMed]

49. AlShehri, S.; Imam, S.S.; Altamimi, M.A.; Hussain, A.; Shakeel, F.; AlShehri, A. Stimulatory Effects of Soluplus ${ }^{\circledR}$ on Flufenamic Acid $\beta$-Cyclodextrin Supramolecular Complex: Physicochemical Characterization and Pre-clinical Anti-inflammatory Assessment. AAPS PharmSciTech 2020, 21, 1-13. [CrossRef]

50. Ishiguro, T.; Morishita, E.; Iohara, D.; Hirayama, F.; Wada, K.; Motoyama, K.; Arima, H.; Uekama, K. Some pharmaceutical and inclusion properties of 2-hydroxybutyl- $\beta$-cyclodextrin derivative. Int. J. Pharm. 2011, 419, 161-169. [CrossRef] [PubMed]

51. Shinde, U.A.; Joshi, P.N.; Jain, D.D.; Singh, K. Preparation and Evaluation of N-Trimethyl Chitosan Nanoparticles of Flurbiprofen for Ocular Delivery. Curr. Eye Res. 2019, 44, 575-582. [CrossRef]

52. Wang, H.-B.; Yang, F.-F.; Gai, X.-M.; Cheng, B.-C.; Li, J.-Y.; Pan, H.; Yang, X.-G.; Pan, W.-S. A pH-independent instantaneous release of flurbiprofen: A study of the preparation of complexes, their characterization and in vitro/in vivo evaluation. Drug Dev. Ind. Pharm. 2017, 43, 1460-1471. [CrossRef]

53. Vega, E.; Egea, M.A.; Garduño-Ramirez, M.L.; Garcia, M.L.; Sanchez, E.; Espina, M.; Calpena, A.C. Flurbiprofen PLGA-PEG nanospheres: Role of hydroxy- $\beta$-cyclodextrin on ex vivo human skin permeation and in vivo topical anti-inflammatory efficacy. Colloids Surf. B Biointerfaces 2013, 110, 339-346. [CrossRef]

54. Li, D.X.; Han, M.J.; Balakrishnan, P.; Yan, Y.D.; Oh, D.H.; Joe, J.H.; Seo, Y.; Kim, J.O.; Park, S.M.; Yong, C.S.; et al. Enhanced oral bioavailability of flurbiprofen by combined use of micelle solution and inclusion compound. Arch. Pharmacal Res. 2010, 33, 95-101. [CrossRef]

55. Zhang, L.; Zhang, Q.; Wang, X.; Zhang, W.; Lin, C.; Chen, F.; Yang, X.; Pan, W. Drug-in-cyclodextrin-in-liposomes: A novel drug delivery system for flurbiprofen. Int. J. Pharm. 2015, 492, 40-45. [CrossRef] [PubMed]

56. Zhao, X.; Li, W.; Luo, Q.; Zhang, X. Enhanced bioavailability of orally administered flurbiprofen by combined use of hydroxypropyl-cyclodextrin and poly(alkyl-cyanoacrylate) nanoparticles. Eur. J. Drug Metab. Pharmacokinet. 2013, 39, 61-67. [CrossRef]

57. Celebioglu, A.; Uyar, T. Fast Dissolving Oral Drug Delivery System Based on Electrospun Nanofibrous Webs of Cyclodextrin/Ibuprofen Inclusion Complex Nanofibers. Mol. Pharm. 2019, 16, 4387-4398. [CrossRef]

58. Volkova, T.; Surov, A.; Terekhova, I. Metal-organic frameworks based on $\beta$-cyclodextrin: Design and selective entrapment of non-steroidal anti-inflammatory drugs. J. Mater. Sci. 2020, 55, 13193-13205. [CrossRef]

59. Rehman, K.; Amin, M.; Muda, S. Influence of Beta-cyclodextrin and Chitosan in the Formulation of a Colon-Specific Drug Delivery System. Drug Res. 2013, 63, 657-662. [CrossRef] [PubMed]

60. Marianecci, C.; Rinaldi, F.; Esposito, S.; Di Marzio, L.; Carafa, M. Niosomes encapsulating ibuprofen-cyclodextrin complexes: Preparation and characterization. Curr. Drug Targets 2013, 14, 1070-1078. [CrossRef] 
61. Li, H.; Lv, N.; Li, X.; Liu, B.; Feng, J.; Ren, X.; Guo, T.; Chen, D.; Stoddart, J.F.; Gref, R.; et al. Composite CD-MOF nanocrystalscontaining microspheres for sustained drug delivery. Nanoscale 2017, 9, 7454-7463. [CrossRef]

62. Hartlieb, K.J.; Ferris, D.P.; Holcroft, J.M.; Kandela, I.; Stern, C.L.; Nassar, M.S.; Botros, Y.Y.; Stoddart, J.F. Encapsulation of Ibuprofen in CD-MOF and Related Bioavailability Studies. Mol. Pharm. 2017, 14, 1831-1839. [CrossRef]

63. Felton, L.A.; Popescu, C.; Wiley, C.; Esposito, E.X.; Lefèvre, P.; Hopfinger, A.J. Experimental and Computational Studies of Physicochemical Properties Influence NSAID-Cyclodextrin Complexation. AAPS PharmSciTech 2014, 15, 872-881. [CrossRef]

64. Mohamed, M.A.H.; Mahmoud, A.A. Formulation of Indomethacin Eye Drops via Complexation with Cyclodextrins. Curr. Eye Res. 2010, 36, 208-216. [CrossRef]

65. Ribeiro-Rama, A.C.; Figueiredo, I.V.; Veiga, F.J.; Castel-Branco, M.M.; Cabrita, A.M.S.; Caramona, M.M. Hepatic and renal toxicities of indomethacin acid, salt form and complexed forms with hydroxypropyl- $\beta$-cyclodextrin on Wistar rats after oral administration. Fundam. Clin. Pharmacol. 2010, 25, 599-607. [CrossRef]

66. Vranić, E.; Uzunović, A. Dissolution Studies of Physical Mixtures of Indomethacin with Alpha- and Gamma-Cyclodextrins. Bosn. J. Basic Med. Sci. 2010, 10, 197-203. [CrossRef] [PubMed]

67. Cirri, M.; Bragagni, M.; Mennini, N.; Mura, P. Development of a new delivery system consisting in "drug-in cyclodextrin-in nanostructured lipid carriers" for ketoprofen topical delivery. Eur. J. Pharm. Biopharm. 2012, 80, 46-53. [CrossRef]

68. Grecu, M.; Năstasă, V.; Ilie, C.; Miron, L.D.; Mareş, M. Comparative assessment of effectiveness of ketoprofen and ketoprofen/betacyclodextrin complex in two experimental models of inflammation in rats. Lab. Anim. 2014, 48, 20-26. [CrossRef]

69. Moutasim, M.Y.; ElMeshad, A.N.; El-Nabarawi, M.A. A pharmaceutical study on lornoxicam fast disintegrating tablets: Formulation and in vitro and in vivo evaluation. Drug Deliv. Transl. Res. 2017, 7, 450-459. [CrossRef]

70. Ammar, H.O.; Ghorab, M.; Mahmoud, A.A.; Makram, T.S.; Noshi, S.H. Topical liquid crystalline gel containing lornoxicam/cyclodextrin complex. J. Incl. Phenom. Macrocycl. Chem. 2011, 73, 161-175. [CrossRef]

71. Bramhane, D.M.; Saindane, N.S.; Vavia, P.R. Inclusion complexation of weakly acidic NSAID with $\beta$-cyclodextrin: Selection of arginine, an amino acid, as a novel ternary component. J. Incl. Phenom. Macrocycl. Chem. 2010, 69, 453-460. [CrossRef]

72. Samprasit, W.; Akkaramongkolporn, P.; Kaomongkolgit, R.; Opanasopit, P. Cyclodextrin-based oral dissolving films formulation of taste-masked meloxicam. Pharm. Dev. Technol. 2017, 23, 530-539. [CrossRef] [PubMed]

73. Samprasit, W.; Akkaramongkolporn, P.; Ngawhirunpat, T.; Rojanarata, T.; Opanasopit, P. Formulation and evaluation of meloxicam oral disintegrating tablet with dissolution enhanced by combination of cyclodextrin and ion exchange resins. Drug Dev. Ind. Pharm. 2014, 41, 1006-1016. [CrossRef]

74. Rein, S.M.T.; Lwin, W.W.; Tuntarawongsa, S.; Phaechamud, T. Meloxicam-loaded solvent exchange-induced in situ forming beta-cyclodextrin gel and microparticle for periodontal pocket delivery. Mater. Sci. Eng. C 2020, 117, 111275. [CrossRef] [PubMed]

75. Jafar, M.; Salahuddin, M.; Kayed, T.S.; Ahmad, N.; Al-Eid, H.A.; Al-Qarros, A.H. Buoyant in situ Gels of Meloxicam-bCyclodextrin-Triethanolamine Ternary Complex for Oral Delivery; From a Box-Behnken Experimental Design to in vivo Activity Detail. Asian J. Chem. 2017, 29, 1275-1284. [CrossRef]

76. Ainurofiq, A.; Choiri, S. Development and optimization of a meloxicam/ $\beta$-cyclodextrin complex for orally disintegrating tablet using statistical analysis. Pharm. Dev. Technol. 2016, 23, 464-475. [CrossRef]

77. Shende, P.K.; Gaud, R.; Bakal, R.; Patil, D. Effect of inclusion complexation of meloxicam with $\beta$-cyclodextrin- and $\beta$-cyclodextrinbased nanosponges on solubility, in vitro release and stability studies. Colloids Surf. B Biointerfaces 2015, 136, 105-110. [CrossRef]

78. Radia, O.; Rogalska, E.; Moulay-Hassane, G. Preparation of meloxicam- $\beta$-cyclodextrin-polyethylene glycol 6000 ternary system: Characterization, in vitro and in vivo bioavailability. Pharm. Dev. Technol. 2011, 17, 632-637. [CrossRef]

79. Rasool, B.K.A.; Gareeb, R.H.; Fahmy, S.A.; Rasool, A.A.A. Meloxicam $\beta$-cyclodextrin transdermal gel: Physicochemical characterization and in vitro dissolution and diffusion studies. Curr Drug Deliv. 2011, 8, 381-391. [CrossRef] [PubMed]

80. Awasthi, S.S.; Kumar, T.G.; Manisha, P.; Preeti, Y.; Kumar, S.S. Development of meloxicam formulations utilizing ternary com-plexation for solubility enhancement. Pak. J. Pharm Sci. 2011, 24, 533-538.

81. Janovsky, M.; Doležal, T.; Prochazkova, M.; Sliva, J.; Kršiak, M. Influence on analgesic activity and serum levels after meloxicam complexation with beta-cyclodextrin in mice and rats. Arzneimittelforschung 2010, 60, 320-323. [CrossRef] [PubMed]

82. Samprasit, W.; Rojanarata, T.; Akkaramongkolporn, P.; Ngawhirunpat, T.; Sila-On, W.; Opanasopit, P. Improvement of drug loading onto ion exchange resin by cyclodextrin inclusion complex. Drug Dev. Ind. Pharm. 2012, 39, 1672-1680. [CrossRef]

83. Tang, P.; Sun, Q.; Zhao, L.; Pu, H.; Yang, H.; Zhang, S.; Gan, R.; Gan, N.; Li, H. Mesalazine/hydroxypropyl- $\beta$ cyclodextrin/chitosan nanoparticles with sustained release and enhanced anti-inflammation activity. Carbohydr. Polym. 2018, 198, 418-425. [CrossRef] [PubMed]

84. Elkordy, A.A.; Ashoore, A.; Essa, E.A. Complexation of naproxen with beta-cyclodextrin with and without poloxamer 407 to enhance drug dissolution. J. Appl. Pharm. 2012, 3, 614-627.

85. Shelley, H.; Grant, M.; Smith, F.T.; Abarca, E.M.; Babu, R.J. Improved Ocular Delivery of Nepafenac by Cyclodextrin Complexation. AAPS PharmSciTech 2018, 19, 2554-2563. [CrossRef]

86. Shelley, H.; Rodriguez-Galarza, R.M.; Duran, S.H.; Abarca, E.M.; Babu, R.J. In Situ Gel Formulation for Enhanced Ocular Delivery of Nepafenac. J. Pharm. Sci. 2018, 107, 3089-3097. [CrossRef] [PubMed]

87. Lorenzo-Veiga, B.; Diaz-Rodriguez, P.; Alvarez-Lorenzo, C.; Loftsson, T.; Sigurdsson, H.H. In Vitro and Ex Vivo Evaluation of Nepafenac-Based Cyclodextrin Microparticles for Treatment of Eye Inflammation. Nanomaterials 2020, 10, 709. [CrossRef] 
88. Auda, S.H. Nimesulide/Methyl $\beta$-Cyclodextrin Inclusion Complexes: Physicochemical Characterization, Solubility, Dissolution, and Biological Studies. Drug Dev. Res. 2014, 75, 68-75. [CrossRef]

89. Mura, P.; Maestrelli, F.; Aguzzi, C.; Viseras, C. Hybrid systems based on "drug-in cyclodextrin-in nanoclays" for improving oxaprozin dissolution properties. Int. J. Pharm. 2016, 509, 8-15. [CrossRef]

90. Maestrelli, F.; Cirri, M.; Mennini, N.; Zerrouk, N.; Mura, P. Improvement of oxaprozin solubility and permeability by the combined use of cyclodextrin, chitosan, and bile components. Eur. J. Pharm. Biopharm. 2011, 78, 385-393. [CrossRef] [PubMed]

91. Maestrelli, F.; Mura, P.; Cirri, M.; Mennini, N.; Ghelardini, C.; Mannelli, L.D.C. Development and characterization of fast dissolving tablets of oxaprozin based on hybrid systems of the drug with cyclodextrins and nanoclays. Int. J. Pharm. 2017, 531, 640-649. [CrossRef] [PubMed]

92. Mennini, N.; Maestrelli, F.; Cirri, M.; Mura, P. Analysis of physicochemical properties of ternary systems of oxaprozin with randomly methylated-ß-cyclodextrin and 1 -arginine aimed to improve the drug solubility. J. Pharm. Biomed. Anal. 2016, 129, 350-358. [CrossRef]

93. Mennini, N.; Cirri, M.; Maestrelli, F.; Mura, P. Comparison of liposomal and NLC (nanostructured lipid carrier) formulations for improving the transdermal delivery of oxaprozin: Effect of cyclodextrin complexation. Int. J. Pharm. 2016, 515, 684-691. [CrossRef] [PubMed]

94. Mura, P.; Maestrelli, F.; Cecchi, M.; Bragagni, M.; Almeida, A. Development of a new delivery system consisting in 'drug-in cyclodextrin-in PLGA nanoparticles. J. Microencapsul. 2010, 27, 479-486. [CrossRef]

95. Mishra, M.; Chawla, V.; Chawla, P. Pectin, beta-cyclodextrin, chitosan and albumin based gastroprotective systems for piroxicam maleate: Synthesis, characterization and biological evaluation. Int. J. Biol. Macromol. 2019, 122, 127-136. [CrossRef] [PubMed]

96. Kontogiannidou, E.; Ferrari, M.; Deligianni, A.-D.; Bouropoulos, N.; Andreadis, D.A.; Sorrenti, M.; Catenacci, L.; Nazari, K.; Arshad, M.S.; Chang, M.-W.; et al. In Vitro and Ex Vivo Evaluation of Tablets Containing Piroxicam-Cyclodextrin Complexes for Buccal Delivery. Pharmaceutics 2019, 11, 398. [CrossRef] [PubMed]

97. Bouchal, F.; Skiba, M.; Chaffai, N.; Hallouard, F.; Fatmi, S.; Lahiani-Skiba, M. Fast dissolving cyclodextrin complex of piroxicam in solid dispersion Part I: Influence of $\beta-C D$ and HP $\beta-C D$ on the dissolution rate of piroxicam. Int. J. Pharm. 2015, 478, 625-632. [CrossRef] [PubMed]

98. Skiba, M.; Bouchal, F.; Boukhris, T.; Bounoure, F.; Fessi, H.; Fatmi, S.; Chaffai, N. Pharmacokinetic study of an oral piroxicam formulation containing different molar ratios of $\beta$-cyclodextrins. J. Incl. Phenom. Macrocycl. Chem. 2012, 75, 311-314. [CrossRef]

99. Keles, G.T.; Topcu, I.; Ekici, Z.; Yentür, A. Evaluation of piroxicam- $\beta$-cyclodextrin as a preemptive analgesic in functional endoscopic sinus surgery. Braz. J. Med. Biol. Res. 2010, 43, 806-811. [CrossRef] [PubMed]

100. Alsarra, I.A.; Ahmed, M.O.; Alanazi, F.K.; Eltahir, K.E.H.; Alsheikh, A.M.; Neau, S.H. Influence of Cyclodextrin Complexation with NSAIDs on NSAID/Cold Stress-Induced Gastric Ulceration in Rats. Int. J. Med. Sci. 2010, 7, 232-239. [CrossRef]

101. Haggag, Y.A.; El-Gizawy, S.A.; El-Din, E.E.Z.; El-Shitany, N.A.; Osman, M.A. Sulindac solid dispersions: Development, characterization and in vivo evaluation of ulcerogenic activity in rats. J. Appl. Pharm. Sci. 2016, 6, 22-31. [CrossRef]

102. Sherje, A.P.; Patel, F.; Murahari, M.; Suvarna, V.; Patel, K. Study on effect of L-arginine on solubility and dissolution of Zaltoprofen: Preparation and characterization of binary and ternary cyclodextrin inclusion complexes. Chem. Phys. Lett. 2018, 694, 120-128. [CrossRef]

103. Felson, D.T. Safety of Nonsteroidal Antiinflammatory Drugs. N. Engl. J. Med. 2016, 375, 2595-2596. [CrossRef] [PubMed]

104. Noori, S.A.; Aiyer, R.; Yu, J.; White, R.S.; Mehta, N.; Gulati, A. Nonopioid versus opioid agents for chronic neuropathic pain, rheumatoid arthritis pain, cancer pain and low back pain. Pain Manag. 2019, 9, 205-216. [CrossRef] [PubMed]

105. Rogoveanu, O.C.; Streba, C.T.; Vere, C.C.; Petrescu, L.; Trăistaru, R. Superior digestive tract side effects after prolonged treat-ment with NSAIDs in patients with osteoarthritis. J. Med. Life 2015, 8, 458-461. [PubMed]

106. Kim, D.-H.; Lee, S.-E.; Pyo, Y.-C.; Tran, P.; Park, J.-S. Solubility enhancement and application of cyclodextrins in local drug delivery. J. Pharm. Investig. 2020, 50, 17-27. [CrossRef]

107. Omar, S.M.; Ibrahim, F.; Ismail, A. Formulation and evaluation of cyclodextrin-based nanosponges of griseofulvin as pediatric oral liquid dosage form for enhancing bioavailability and masking bitter taste. Saudi Pharm. J. 2020, 28, 349-361. [CrossRef]

108. Santos, P.L.; Brito, R.G.; Quintans, J.S.; Araujo, A.A.; Menezes, I.R.; Brogden, N.K.; Quintans-Junior, L.J. Cyclodextrins as Complexation Agents to Improve the Anti-inflammatory Drugs Profile: A Systematic Review and Meta-Analysis. Curr. Pharm. Des. 2017, 23. [CrossRef] [PubMed]

109. Saokham, P.; Muankaew, C.; Jansook, P.; Loftsson, T. Solubility of Cyclodextrins and Drug/Cyclodextrin Complexes. Molecules 2018, 23, 1161. [CrossRef]

110. Kurkov, S.V.; Loftsson, T. Cyclodextrins. Int. J. Pharm. 2013, 453, 167-180. [CrossRef]

111. Rizk, M.L.; Zou, L.; Savic, R.M.; Dooley, K.E. Importance of Drug Pharmacokinetics at the Site of Action. Clin. Transl. Sci. 2017, 10, 133-142. [CrossRef]

112. Lennernäs, H. Regional intestinal drug permeation: Biopharmaceutics and drug development. Eur. J. Pharm. Sci. 2014, 57, 333-341. [CrossRef]

113. Vastag, G.; Apostolov, S.; Matijević, B. Prediction of lipophilicity and pharmacokinetics of chloroacetamides by chemomet-ric approach. Iran. J. Pharm. Res. 2018. [CrossRef] 
114. Fine-Shamir, N.; Beig, A.; Miller, J.M.; Dahan, A. The solubility, permeability and the dose as key factors in formulation development for oral lipophilic drugs: Maximizing the bioavailability of carbamazepine with a cosolvent-based formulation. Int. J. Pharm. 2020, 582, 119307. [CrossRef] [PubMed]

115. Jyoti Sen, D.; Patel, J.G. Logarithmic Partition Coefficient Comparison Study and Molecular Weight of Synthesized Prodrugs of Ibuprofen+Paracetamol, Diclofenac Sodium+Paracetamol and Ibuprofen+Diclofenac Sodium. Am. J. Adv. Drug Deliv. 2016, 4. [CrossRef]

116. Youn, Y.-S.; Lee, J.-H.; Jeong, S.-H.; Shin, B.-S.; Park, E.-S. Pharmaceutical Usefulness of Biopharmaceutics Classification System: Overview and New Trend. J. Pharm. Investig. 2010, 40,1-7. [CrossRef]

117. Muankaew, C.; Jansook, P.; Loftsson, T. Evaluation of $\gamma$-cyclodextrin effect on permeation of lipophilic drugs: Application of cellophane/fused octanol membrane. Pharm. Dev. Technol. 2017, 22, 562-570. [CrossRef]

118. Mizera, M.; Muratov, E.N.; Alves, V.M.; Tropsha, A.; Cielecka-Piontek, J. Computer-Aided Discovery of New Solubility-Enhancing Drug Delivery System. Biomolecules 2020, 10, 913. [CrossRef]

119. Yang, J.; Li, K.; He, D.; Gu, J.; Xu, J.; Xie, J.; Zhang, M.; Liu, Y.; Tan, Q.; Zhang, J. Toward a better understanding of metabolic and pharmacokinetic characteristics of low-solubility, low-permeability natural medicines. Drug Metab. Rev. 2020, 52, 19-43. [CrossRef]

120. Ruela, A.L.M.; Perissinato, A.G.; Lino, M.E.D.S.; Mudrik, P.S.; Pereira, G.R. Evaluation of skin absorption of drugs from topical and transdermal formulations. Braz. J. Pharm. Sci. 2016, 52, 527-544. [CrossRef]

121. Agrahari, V.; Mandal, A.; Agrahari, V.; Trinh, H.M.; Joseph, M.; Ray, A.; Hadji, H.; Mitra, R.; Pal, D.; Mitra, A.K. A comprehensive insight on ocular pharmacokinetics. Drug Deliv. Transl. Res. 2016, 6, 735-754. [CrossRef] [PubMed]

122. Wang, Z.; Landy, D.; Sizun, C.; Cézard, C.; Solgadi, A.; Przybylski, C.; De Chaisemartin, L.; Herfindal, L.; Barratt, G.; Legrand, F.-X. Cyclodextrin complexation studies as the first step for repurposing of chlorpromazine. Int. J. Pharm. 2020, $584,119391$. [CrossRef] [PubMed]

123. Schjerning, A.-M.; Mcgettigan, P.; Gislason, G. Cardiovascular effects and safety of (non-aspirin) NSAIDs. Nat. Rev. Cardiol. 2020, 17, 574-584. [CrossRef] [PubMed]

124. Popielec, A.; Loftsson, T. Effects of cyclodextrins on the chemical stability of drugs. Int. J. Pharm. 2017, 531, 532-542. [CrossRef] [PubMed] 